\title{
18. MINERALOGICAL AND GEOCHEMICAL ANALYSES OF SEDIMENTARY SERPENTINITES FROM CONICAL SEAMOUNT (HOLE 778A): IMPLICATION FOR THE EVOLUTION OF SERPENTINE SEAMOUNTS ${ }^{1}$
}

\author{
Yves Lagabrielle, ${ }^{2}$ Anne-Marie Karpoff, ${ }^{3}$ \\ and Joseph Cotten ${ }^{2}$
}

\begin{abstract}
Thirty-five samples from Hole 778A were prepared for X-ray diffraction (XRD) mineralogical analyses and for chemical analyses of major and trace elements. Most of the selected samples were silt- and sand-sized sedimentary serpentinites or microbreccias except for a soft clast of mafic rock, a hard clast of massive serpentinized peridotite, and a pebble of consolidated, undeformed serpentine microbreccia that contained planktonic foraminifers. Both mineralogical and geochemical analyses allow discrimination of three groups among the analyzed samples. These groups correspond to three stratigraphic intervals present along the drilled section.

Group A contains the upper samples (lithologic Unit I). These consist of poorly consolidated serpentine muds carrying hard-rock clasts (serpentinized peridotites, metabasalts). They are characterized by the following mineralogical assemblage: serpentine, Fe-oxides and hydroxides, aragonite, and halite. They exhibit variable $\mathrm{SiO}_{2}, \mathrm{MgO}$ contents, but are characterized by a $\mathrm{SiO}_{2} / \mathrm{MgO}$ ratio near 1 . CaO content is high in relation to development of aragonite. $\mathrm{Al}_{2} \mathrm{O}_{3}$ content is low. Relatively high $\mathrm{K}_{2} \mathrm{O}, \mathrm{Na}_{2} \mathrm{O}$, and $\mathrm{Sr}$ contents are present, presumably in relation to interactions with seawater.

Group B (30-77 mbsf) contains samples exhibiting very homogeneous chemical and mineralogical compositions. They consist of serpentinite microbreccias exhibiting frequent shear structures. Hard-rock clasts are also present (serpentinized peridotites, metabasalts, one possible chert fragment). The mineralogy of the Group B samples is characterized by the presence of serpentine and authigenic minerals: hydroxycarbonates and hydrogrossular. Calcite and chlorite are also present, but all the samples lack aragonite. Their chemical compositions are remarkably similar to compositions of their parent rocks.

Group C contains silt- and sand-sized serpentine and serpentine microbreccias, which are locally rich in red clasts, probably strongly altered (oxidized?) mafic fragments. Intervals having clasts of more diverse origin than those higher in the section were recovered. Clast lithology includes serpentinized peridotites, metabasalts, metavolcaniclastite, meta-olivine gabbro, and amphibolite sandstone. Mineralogy and geochemistry reflect these compositions. Serpentine content of the samples is less than in previous groups. Correlatively, sepiolite, palygorskite, and chlorite-smectite are mineral phases present in the analyzed samples. Accessory igneous minerals (amphiboles, pyroxenes, hematite) also were found. The chemical compositions of most of Group $\mathrm{C}$ samples differ from that of massive serpentinized peridotites. The main differences are (1) higher $\mathrm{SiO}_{2}, \mathrm{CaO}, \mathrm{TiO}_{2}$ and $\mathrm{Al}_{2} \mathrm{O}_{3}$ contents, (2) a $\mathrm{SiO}_{2} / \mathrm{MgO}$ ratio greater than 1, and (3) a negative correlation between $\mathrm{Al}_{2} \mathrm{O}_{3}$, and $\mathrm{MgO}, \mathrm{Cr}$, and $\mathrm{Ni}$. These characteristics suggest new constraints relative to the flow structure of the flank of Conical Seamount.
\end{abstract}

\section{INTRODUCTION}

SeaMARC II surveys in the Mariana forearc domain (Fig. 1) have shown that Conical Seamount and is characterized by a relatively rough topography and the development of numerous small ridges and fractures (Fig. 2) (Fryer et al., 1990). The most spectacular features are the occurrence of highly reflective zones, with more or less sinuous outlines, which have been interpreted as viscous, cold flows of unconsolidated, fine-grained serpentine (Hussong and Fryer, 1985; Fryer et al., 1985; Fryer and Fryer, 1987). At a smaller scale, in-situ observations during dives of the submersible Alvin (Fryer et al., 1987; Fryer et al., 1990) showed these flows to be composed of unconsolidated serpentine muds having clasts of serpentinized ultramafic rocks and associated mafic rocks. Additional information such as data obtained along vertical sections in the flanks of the seamounts is necessary to

\footnotetext{
${ }^{1}$ Fryer, P., Pearce, J. A., Stokking, L. B., et al., 1992. Proc. ODP, Sci. Results, 125: College Station, TX (Ocean Drilling Program).

2 URA CNRS: 1278 and G.D.R. "Genèse et Evolution des Domaines Océaniques," 6 Avenue le Gorgeu, 29287 Brest Cédex, France.

${ }^{3}$ Centre de Géochimie de la Surface, Institut de Géologie, Université Louis Pasteur, 67084 Strasbourg Cédex, France.
}

discuss the details relative to the kinematics and to the processes of emplacement of the serpentine flows.

Three holes drilled in the flanks and at the summit of Conical Seamount during Leg 125 provide new, crucial data relative to the vertical stratigraphy, structure, mineralogy, and geochemistry of the serpentine formations capping the seamount. These data clearly demonstrate that the flanks of the seamount consist of ultramafic material, mostly serpentinite mud, silt, or sand, with a sedimentary fabric, carrying various ultramafic or "exotic" blocks. Analyses of the tectonic fabric of the serpentine formations lead us to confirm the presence of viscous flows on the flank of the seamount (ODP Leg 125 Scientific Party, 1989). But this conclusion remained questionable because some of the tectonic features described from the cores could be drilling disturbances.

Onshore studies thus are needed to confirm or to discuss the processes of flow. We report on mineralogical and geochemical data obtained from 35 samples collected along the 107.6-m-deep section recovered at Site 778. These data are essential because they place new constraints on the evolution of the ultramafic material on the flanks of the seamount. A discussion of the flow mechanisms is presented, based on both mineralogical and geochemical data presented here, with references to the lithology and to the tectonic fabric of the rocks as reported in Reports (Fryer, Pearce, Stokking, et al., 1990) and as briefly summarized below. 


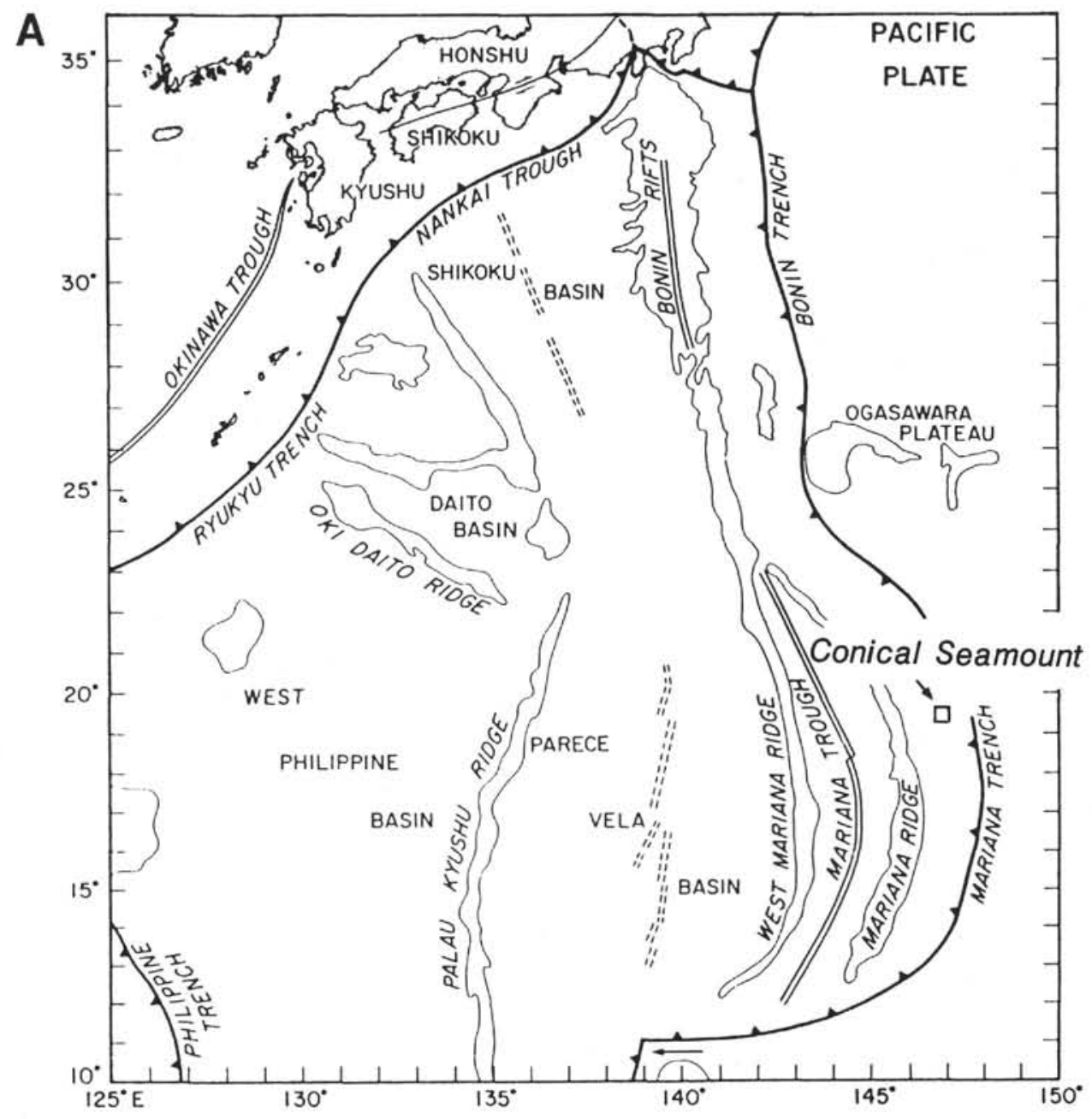

B

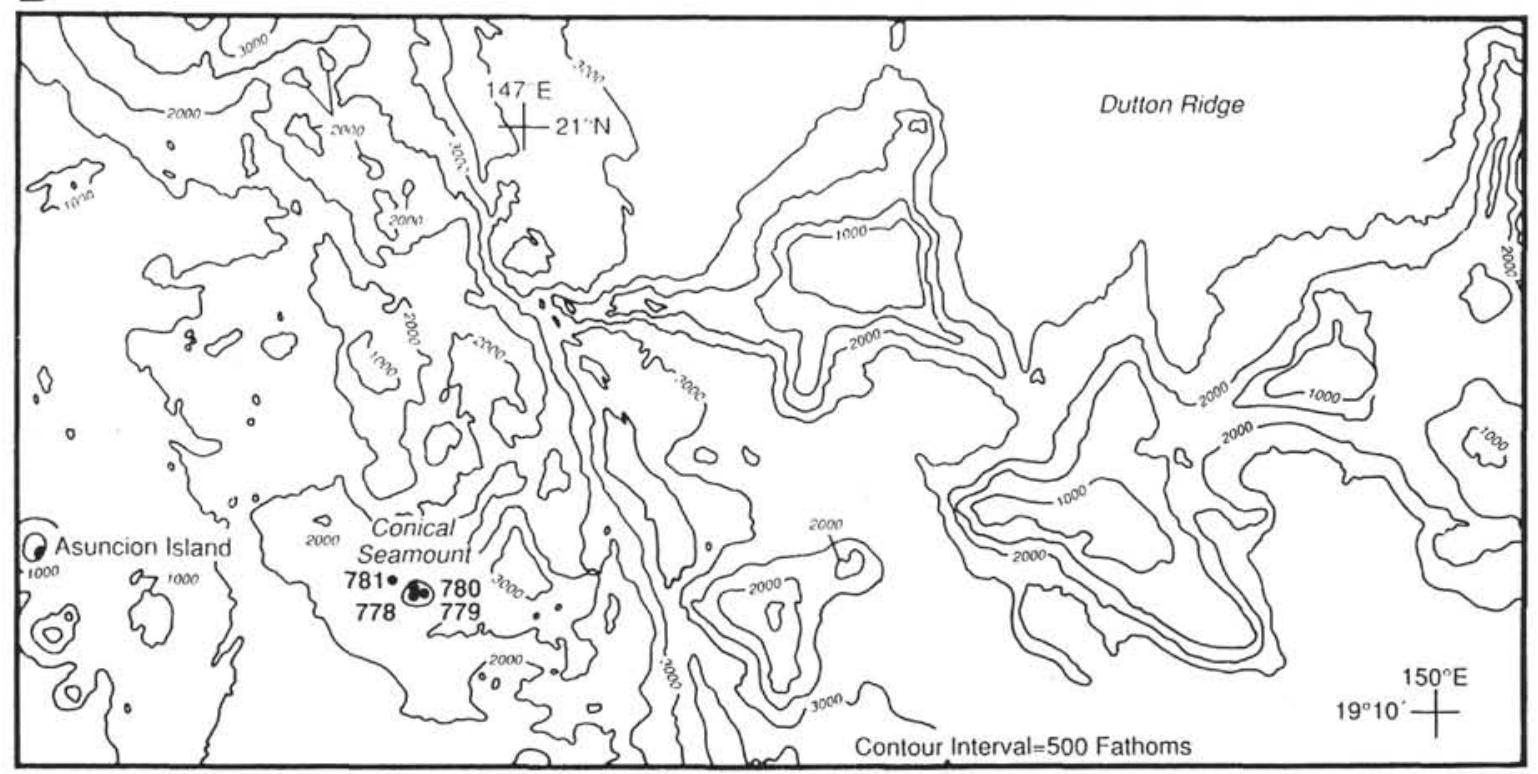

Figure 1. Bathymetry and geological features of the Philippine Sea region (A) and bathymetry of the central Mariana Arc, with locations of Sites 778, 779, and 780 at Conical Seamount $(\mathbf{B})$. 
A

$146^{\circ} 40^{\prime} \mathrm{E}$
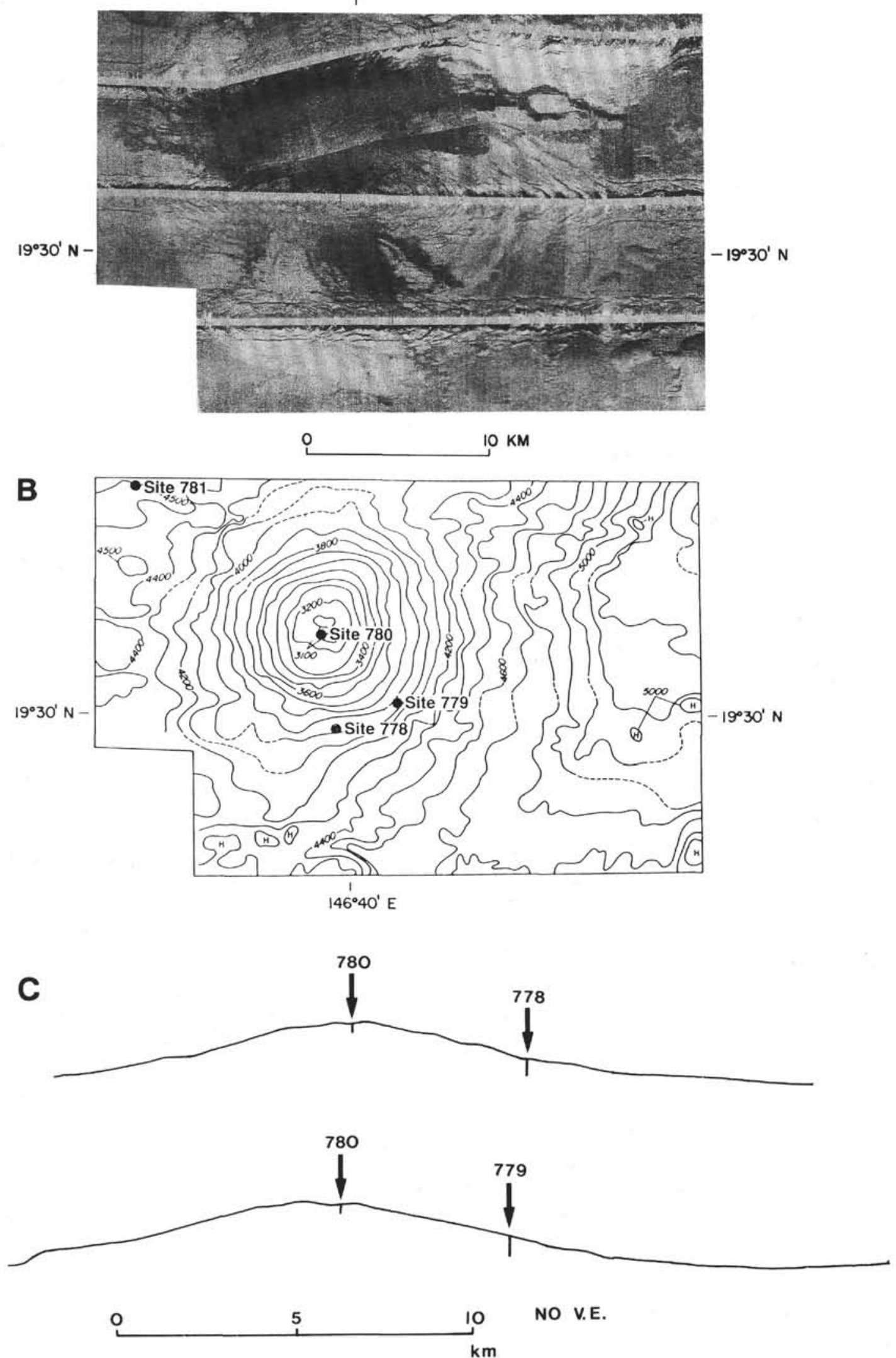

NO V.E.

km

Figure 2. (A) Location of Sites 778, 779, 780, and 781 and the apparent distribution of surface flows from side-scanning sonar imagery (after Fryer et al., 1990). (B). Bathymetric sketch of Conical Seamount in the Mariana forearc. (C) Topographic sections without vertical exaggeration through Sites 778,779 , and 780 are also shown. 


\section{SUMMARY OF MAIN RESULTS OBTAINED AT SITE 778 AND BRIEF DESCRIPTION OF THE SAMPLES}

The analyzed samples come from Hole $778 \mathrm{~A}$; sample numbers carry the prefix 125 for leg number and $778 \mathrm{~A}$ for hole number. In text, for convenience, we shall refer to samples using a simple identification. Sample numbers used here range from 1 to 34 (from top to bottom of the hole), the corresponding ODP numbers are reported in Table 1.

The 107.6-m-thick stratigraphic section recovered at Site 778 on the flank of Conical Seamount (Fig. 3) has been divided into two lithologic units. Criteria used to discriminate between lithologic Units I and II are essentially fabric criteria. Rocks from Unit II are serpentine breccias with a well-defined layering and spectacular shear structures. Color variations at a scale of a few millimeters to a few centimeters, along with variations in the density of millimeter- to centimeter-sized clasts define a crude layering. Anastomosing small-scale shear zones define shear lenses or "phacoids" (Fig. 4). These rocks also show convolute plastic folding of the sedimentary bedding (Fig. 5). By contrast, rocks from Unit I are devoid of post-depositional deformation structures. They consist of almost homogeneous clay-sized serpentine. In addition, the sedimentary serpentinites from Unit I are characterized by the presence of numerous aragonite needles, up to $1 \mathrm{~mm}$ long. This mineral, which is not stable under normal conditions at that depth also has been described in samples recovered by submersible surveying of Conical Seamount (Haggerty, 1987). It has been suggested that aragonite may result from migration of fluids other than normal seawater, for instance, fluids that vent from serpentine seamounts (Haggerty, 1987).

Both sediments from Units I and II contain pebbles and blocks of ultramafic, mafic, and other types of clast that occur either as inclusions in the sedimentary serpentine or as isolated fragments. Clast sizes range from about $15 \mathrm{~cm}$ to less than $1 \mathrm{~mm}$. Shapes are rounded to subrounded. Most of the clasts are jacketed with sheared serpentine clays. Although ultramafic rocks are dominant, the lithology of the clasts is variable. The most abundant clasts are serpentinized, tectonized harzburgites and subordinate dunite $(80 \%)$. The remainder are variably metamorphosed metabasalts (15\%) and other types, including foraminifer-rich, serpentine, undeformed microbreccia (in Section 125-778A-4R-1), siliceous, coarse-grained, red rock, possibly chert (in section 125778A-6R-1), gabbro, amphibolite sandstone (probably metasedimentary), and volcaniclastic rock (in lowest Core 125-778A13R). The metabasalts show either a felted texture with now-altered plagioclase laths in a fine-grained groundmass or typical quench-texture with skeletal plagioclases and spinifex pyroxenes. This latter texture indicates that the metabasalts have been emplaced on the seafloor or at a very shallow level in the crust. Geochemical analyses of the metabasaltic clasts enclosed in the sedimentary serpentines of Conical Seamount reveal that these rocks belong to different geochemical groups (Johnson, this volume). Island-arc tholeiite (IAT) and volcanic rocks having boninitic affinities were the primary types recovered from Sites 778 , 779 , and 780 , and few fragments with mid-ocean ridge basalt (MORB) and more alkalic compositions were also recovered (Johnson, this volume). Basaltic lavas recovered from dredge hauls located very close to the seamount along walls of a graben also show different composition in relationship with different magma sources (Johnson and Fryer, 1990). In the basal part of the hole, mafic, commonly oxidized (reddish) fragments of small size (around $1 \mathrm{~mm}$ ) become abundant. In Cores 125-778A-12R and 125-778A-13R, contorted, brown-red layers, some up to a centimeter thick, contain abundant red (mafic?) clasts.
The occurrence of numerous exotic blocks of various lithologies and from diverse origins (mantle-derived rocks, mafic plutonic, and volcanic of diverse geochemical affinities; sedimentary and volcano-sedimentary rocks) is one of the basic characteristic of Hole 778A. Such characteristic were also found at other drill sites on Conical Seamount (Johnson, this volume). This feature places a major constraint on the understanding of the mechanism responsible for the formation and evolution of the seamount.

All 13 cores of Hole 778A, except Cores 125-778A-3R and 125-778A-10R, were sampled. Most of the selected samples are silt- or sand-sized sedimentary serpentinites or microbreccias. Samples 1 to 15 belong to lithologic Unit I and Samples 16 to 35 belong to lithologic Unit II. Analysis 11 is from a soft, green clast in a serpentine microbreccia. This clast shows geochemical affinities with mafic rocks. Analysis 14 is from a hard clast of massive serpentinized peridotite. This analysis will be used as a reference for the composition of parent rock. It is similar to that of other clasts of massive ultramafics from Sites 778, 779, and 780. Analysis 15 is from a pebble of consolidated, undeformed, serpentine microbreccia containing numerous $(10 \%)$ planktonic foraminifers of Pleistocene age (absolute age approximately $1.45 \mathrm{Ma}$, Zone N22 according to determinations conducted on board the ship and on shore; G. Milner, pers. comm.,1990; this age is confirmed by the nannofossils present in the sample). This rock also shows numerous millimetric spherolites that are composed of aragonitic, radial needles.

Based on their texture, two main types of rock can be defined among the samples selected. These types correspond to the types defined in lithologic Units I and II. The first type (Samples 1 to 13) includes samples of very soft, hydrated material that may have been soupy in the first cores. These samples show no peculiar post-depositional structure and consist mostly of serpentine mud (now consolidated) in which rounded, centimeter- to decimetersized clasts of mostly serpentinized peridotites are present. The second type (samples 16 to 35 ) corresponds to more deformed, and locally more consolidated material referred to as "phacoidal" sheared serpentinite in Leg 125 site reports (Fryer, Pearce, Stokking, et al., 1990). In thin section, selected samples from this latter type show a typical brecciated texture with millimeter-sized clasts of serpentine with various textures, isolated crystals (including more or less serpentinized pyroxenes), spinel fragments, and magnetite aggregates, all of which are enclosed in a matrix composed of an assemblage of serpentine flakes. In some of these samples a well-developed shear fabric is present. The serpentine clasts are plastically deformed and exhibit a typical, lens-shaped habit. The deformed clasts are characterized by asymmetrical tails related to deformation, with a simple shear component. The matrix of the breccia is also cross-cut by numerous small-scale shear planes. Because of the weak, preferred orientation of these tectonic markers, no homogeneous sense of shear can be clearly defined in the samples, even those in which three sections in three different planes have been prepared. In this second type of sample, the clasts are generally $1 \mathrm{~mm}$ in their longest dimension. In a few cases only, the longest dimension of clasts reaches 4 to $5 \mathrm{~mm}$.

\section{SAMPLE PREPARATION AND ANALYTICAL METHODS}

The selected samples were recovered from the cores when they were not totally dehydrated. They were simply cut using a knife or directly sampled with sampling boxes. Later, we found it necessary to use a saw to cut all the samples collected. The difficulty in cutting the samples on shore indicates that the rocks initially contained a considerable amount of interstitial water. Porosities measured on board were high, generally in excess of 
Table 1. X-ray diffraction data from bulk rocks.

\begin{tabular}{|c|c|c|c|c|c|c|c|c|c|c|c|c|c|}
\hline $\begin{array}{l}\text { Sample Number } \\
\text { (this study) }\end{array}$ & $\begin{array}{l}\text { depth } \\
\text { (mbsf) }\end{array}$ & $\begin{array}{l}\text { Core-section } \\
\text { int. }(\mathrm{cm})\end{array}$ & $\begin{array}{l}\text { Serp } \\
\text { Int. }\end{array}$ & $\begin{array}{l}\text { ntines } \\
\text { Pos. }\end{array}$ & Sepiolite & Palygorskite & Chlorite & Aragonite & $\begin{array}{l}\text { Hyd. carb } \\
\text { int. }\end{array}$ & Calcite & Iron oxides & Others & Others \\
\hline \multicolumn{14}{|l|}{$125-778 \mathrm{~A}-$} \\
\hline 1 & 0.19 & IR-1, 19-20 & 7 & 7,23 & & & & & & & G & & \\
\hline 2 & 0.23 & IR-1, 23-24 & 7 & 7,26 & & & & Sp. & & & G & & \\
\hline 3 & 0.47 & IR-1, 47-49 & 9 & 7,23 & & & & & ++ & & tr $\mathrm{H}$ & & \\
\hline 4 & 1.12 & IR-1, 112-114 & 12 & 7,21 & & & tr & & H & & tr & & \\
\hline 5 & 1.76 & 1R-2, 26-28 & 12 & 7,29 & & & & & & tr & & Epidote? & \\
\hline 6 & 2.58 & IR-2, 108-110 & 16 & 7,21 & & & tr & Sp. & & & & & \\
\hline 7 & 3.44 & IR-3, 44-46 & 12 & 7,25 & & & tr - & & & & $\mathrm{H}$ & & \\
\hline 8 & 4.82 & IR-4, $32-34$ & 9 & 7,23 & & & & Sp. tr & & & tr. $\mathrm{H}$ & & \\
\hline 9 & 5.10 & IR-4, $60-62$ & 9 & 7.23 & & & & Sp. & & & tr. $\mathrm{G}+\mathrm{H}$ & & \\
\hline 10 & 6.25 & IR-5, 25-27 & 9 & 7,23 & & & tr & Arag. & & & G & Epidote? & \\
\hline 11 & 6.25 & IR-5, 25-27 (Clast) & 3 & 7,15 & & & $\mathrm{tr}+\mathrm{kaol}$ & & & Dol.? & & Epidote? & Feld. or pyrox. \\
\hline 12 & 6.70 & IR-CC, $5-7$ & 7 & 7,25 & & & tr - & Arag. sp. & + & & & & \\
\hline 13 & 7.11 & $2 \mathrm{R}-1,41-43$ & 12 & 7,25 & & & & Sp. & ++ & + & & & \\
\hline 14 & 20.33 & $4 R-1,13-14$ & 12 & 7,24 & & & & & + & & & & \\
\hline 15 & 20.45 & $4 \mathrm{R}-1,23-25$ & 7 & 7,20 & & & & Sp.tr & & tr & tr & Hydrogarnet & Plagio. \\
\hline 16 & 29.95 & $5 \mathrm{R}-1,25-27$ & 20 & 7,22 & & & 1 & & t++ & & & & \\
\hline 17 & 39.24 & 5R-CC, 4-8 & 16 & 7,23 & tr? & & tr & & + & & & & \\
\hline 18 & 39.63 & $6 \mathrm{R}-1,43-45$ & 16 & 7,25 & & & $\mathrm{tr}+$ & & & & & & \\
\hline 19 & 40.60 & $6 \mathrm{R}-1,140-142$ & 20 & 7.20 & & & tr & & & & & & \\
\hline 20 & 48.95 & $7 \mathrm{R}-1,25-28$ & 20 & 7,25 & & & tr... & & + & tr & & & \\
\hline 21 & 49.04 & $7 \mathrm{R}-1.34-36$ & 20 & 7.26 & & & & & ++ & + & & & \\
\hline 22 & 49.39 & $7 \mathrm{R}-1,69-72$ & 16 & 7,24 & & & tr & & n+t+ & + & & Hydrogarnet & \\
\hline 23 & 49.80 & $7 \mathrm{R}-1,110-112$ & 16 & 7,27 & & & tot & & n+t+ & + & & Hydrogarnet & \\
\hline 24 & 59.52 & $8 \mathrm{R}-1,132-135$ & 20 & 7,24 & & & & & ++ & + & & Hydrogarnet & \\
\hline 25 & 69.24 & $9 \mathrm{R}-1,104-106$ & 20 & 7,23 & & & ++ & & & & & & \\
\hline 26 & 69.75 & $9 \mathrm{R}-2,5-7$ & 20 & 7.23 & & & ++ & & ++ & tr & & & \\
\hline 27 & 82.71 & $11 \mathrm{R}-1,41-43$ & 5 & 7,21 & ++ & & $+(\mathrm{C}-\mathrm{Sm})$ & & & + & & Amphib., pyrox. & \\
\hline 28 & 82.95 & $11 \mathrm{R}-1,65-68$ & 9 & 7,27 & ++ & & $+(\mathrm{C}-\mathrm{Sm})$ & & & tr & & Amphib.? & \\
\hline 29 & 83.87 & IIR-2, 7-9 & 12 & 7,26 & & ++ & & & & tr & & & \\
\hline 30 & 90.60 & $12 \mathrm{R}-1,80-84$ & 16 & 7.22 & & & tr & & & & & & \\
\hline 31 & 91.94 & $12 \mathrm{R}-2,64-68$ & 25 & 7,20 & & & + & & & + & & & \\
\hline 32 & 98.53 & $13 \mathrm{R}-1,23-25$ & 3 & 7,26 & t+t & & $+\mathrm{Sm}$ & & & Dol. & & Amphib. Pyrox.; Epidote? & \\
\hline 33 & 99.27 & $13 \mathrm{R}-1,97-100$ & 5 & 7,24 & +++ & & & & & & $\mathrm{H}$ ? & & \\
\hline 34 & 99.82 & $13 R-2,4-6$ & 1 & 7,26 & n+t+ & & & & & & & Amphib.-pyrox. tr & \\
\hline 35 & 107.60 & 13R-CC, 14-16 & 5 & 7,25 & ++ & & & & & & & & \\
\hline
\end{tabular}

Int. = peak intensity, Pos. = peak position, $\mathrm{t}=$ trace, kaol. $=$ kaolinite, $\mathrm{C}$-Sm $=$ chlorite-smectite, $\mathrm{Sp} .=$ untypical aragonite, $\mathrm{Dol},=$ dolomite, $\mathrm{G}=$ goethite, $\mathrm{H}=$ hematite, Amphib. $=$ amphibole, Pyrox. $=$ pyroxene, Feld. $=$ feldspath. Plagio. $=$ plagioclase 


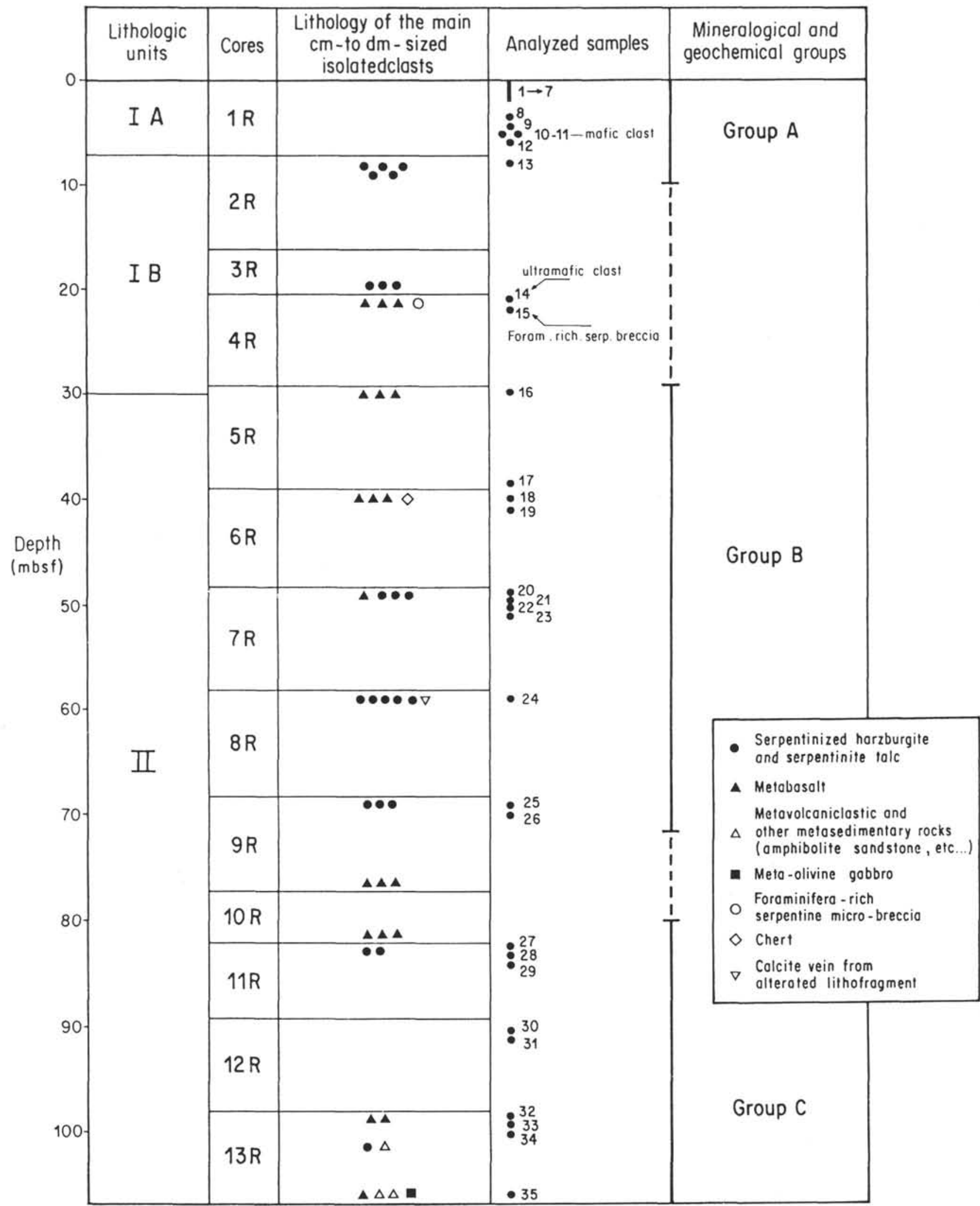

Figure 3. Cores and lithologic units of Hole 778A section and location of the analyzed samples. Lithology of the main isolated clasts recovered from the cores is reported. The three groups of samples $(\mathbf{A}, \mathbf{B}, \mathbf{C})$ are discriminated according to the mineralogical and geochemical characteristics defined in the text. All samples are poorly consolidated serpentine microbreccias, sandstones, and siltsones except Samples 11 (a soft green clast with a mafic chemical composition), 14 (a hard ultramafic clast of massive serpentinized peridotite), and 15 (a pebble of consolidated, foraminiferrich serpentine microbreccias). 

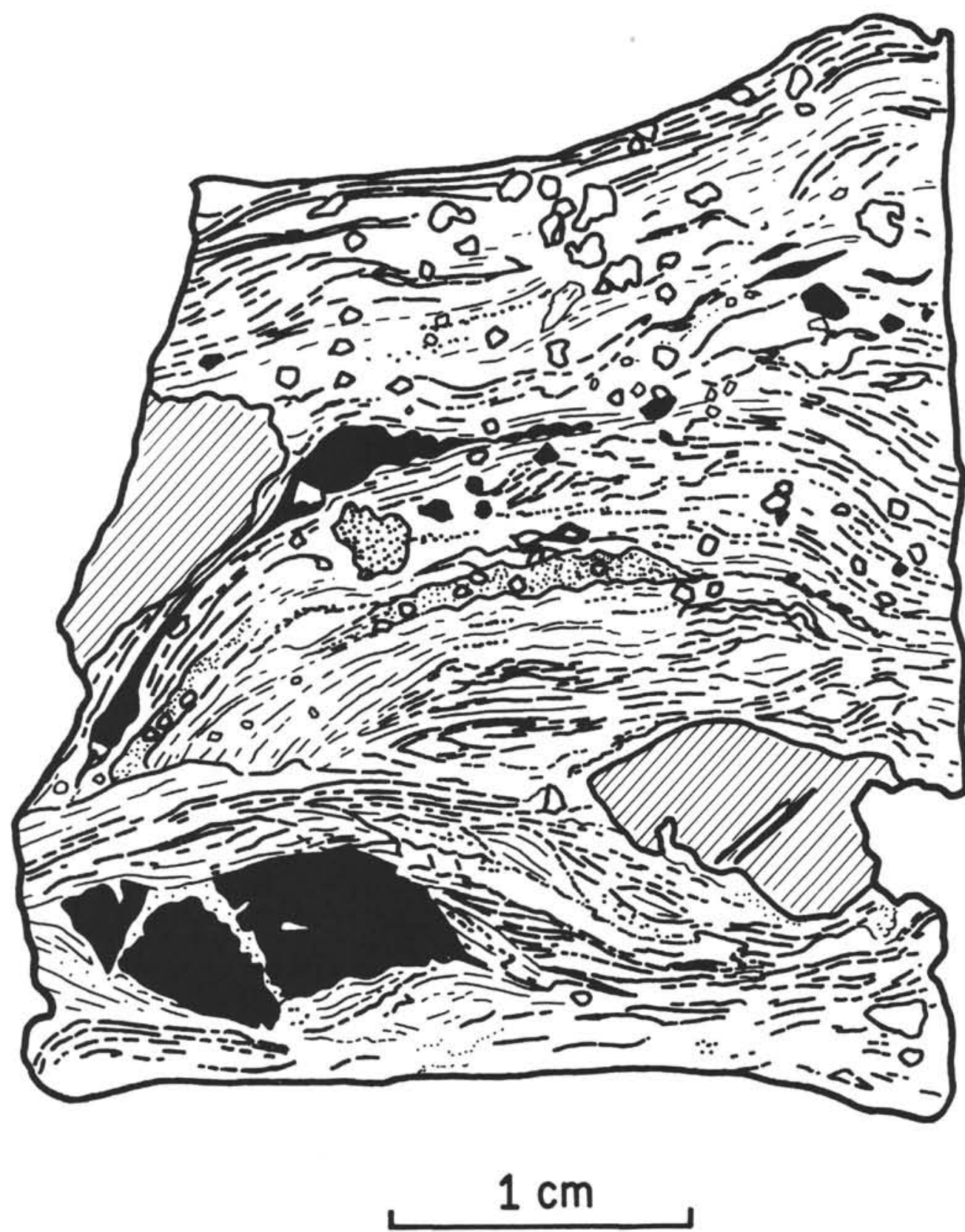

Figure 4. Typical anastomosing cleavage and shear fabric of layered serpentine microbreccia from Hole 778A (Sample 125-778A-7R-1, 11-20 cm).

$40 \%$, with values as high as $86 \%$. No density values are available from Site 778, but densities measured in serpentine muds from Site 779 are very low, with values ranging from 1.4 to 2.2 . A part of each bulk sample was prepared by induration to make a thin section. The remainder of the bulk sample was used for chemical and mineralogical investigations. Most of each powdered sample (weights ranging from 3.0 to $4.0 \mathrm{~g}$ ) were used for chemical analyses conducted in Brest. Major- and trace-element compositions including $\mathrm{Li}, \mathrm{Rb}, \mathrm{Sr}, \mathrm{Ba}, \mathrm{V}, \mathrm{Cr}, \mathrm{Co}, \mathrm{Ni}, \mathrm{Cu}$, and $\mathrm{Zn}$ were determined using atomic flame emission and atomic absorption spectrophotometry. The mineral assemblage was determined by X-ray diffraction on powdered samples using a Philips PW1710 diffractometer. Unoriented powders were run between $3^{\circ}$ and $65^{\circ}$ $2 \Theta$ at $40 \mathrm{kV} / 20 \mathrm{~mA}$, using $\mathrm{CuK} \alpha$ radiation, Ni filter, and $0.01 \%$ scan speed.
Microprobe analyses were performed using the automatized microprobe "Ouest" (IFREMER-UBO, Brest) or an EDS microprobe (Tracor system) coupled to the scanning electron microscope JEOL JMS840 (Strasbourg).

\section{MINERALOGY OF THE SERPENTINE SEDIMENTS}

$\mathrm{X}$-ray diffraction data from bulk rocks are reported in Table 1. The mineral assemblage contains serpentines, clay minerals, carbonates, Fe-oxyhydroxides, and mafic minerals, in variable proportions. The large amounts of secondary halite of the uppermost soft samples confirm their large water contents. The specificities of these minerals and the significance of their occurrence and association are discussed below.

Serpentine minerals dominate all the samples. Although the routine XRD method used does not allow the crystallographic 


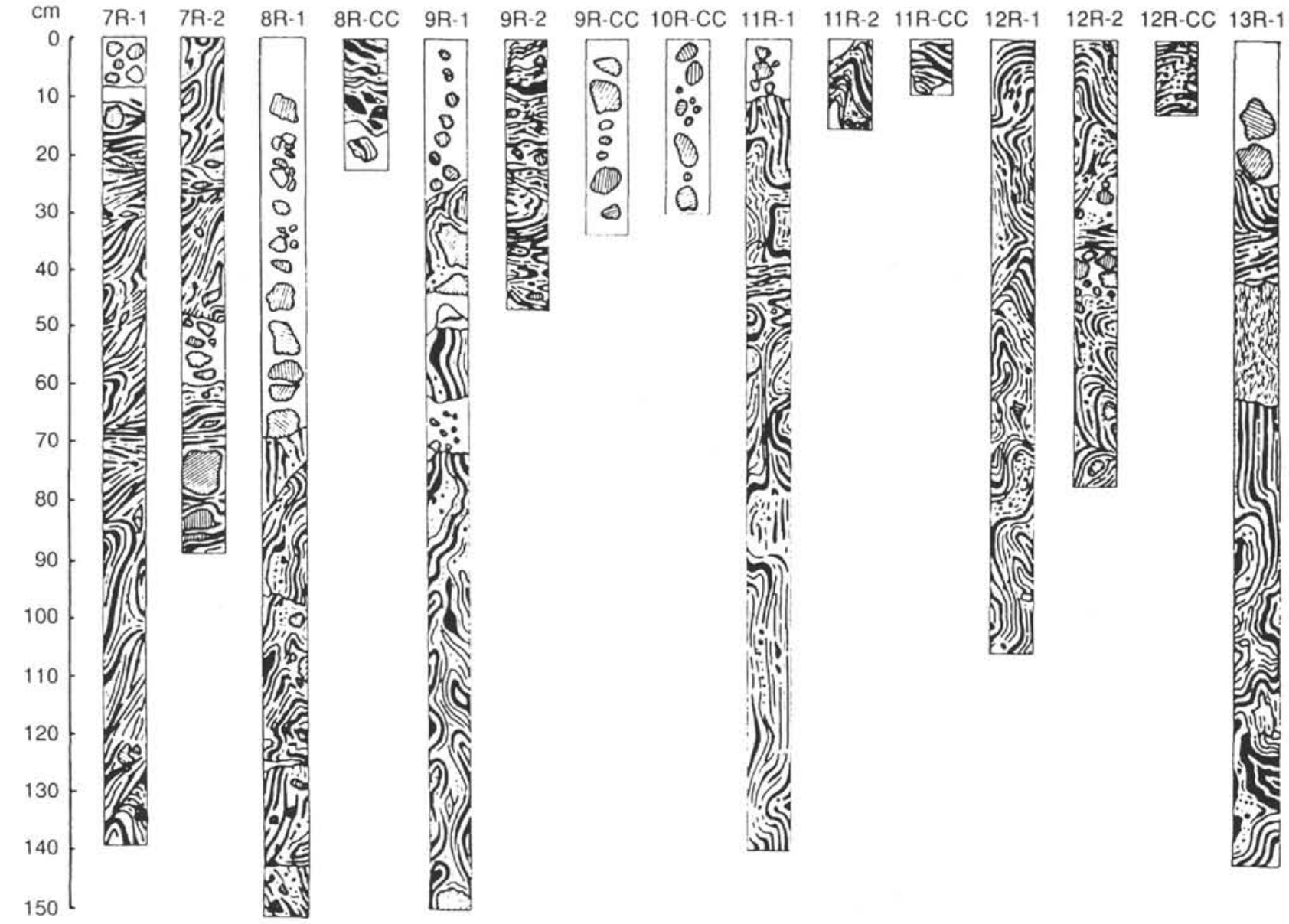

Figure 5. Plastic folds in layered serpentine microbreccias of Hole 778A. Sets of folds with opposite hinges and axial symmetry as well as areas with vertical foliation probably indicate drilling disturbance.

characteristics and polytypes of the serpentine phases to be specified accurately, the position of the main peak, which is related to the chemical composition of serpentine, gives information about the type of analyzed mineral. Within the serpentine mineral group that comprises three sets of solid solutions between lizardite, chrysotile, and antigorite, the named Al-serpentines (with high $\mathrm{Al}$ octahedral substitutions and close to the antigorite pole) are characterized by a reflection at 7.17-7.09 $\AA$, and the $\mathrm{Mg}$-serpentines (such as the chrysotile and lizardite end-members) by their main peak located above $7.31 \AA$ (Whittaker and Zussman, 1956; Page, 1968; Mumpton and Thompson, 1975; Wicks and O'Hanley, 1988). Detailed crystallographic identification of the serpentine minerals must be made on separated fractions by specific XRD, TEM-STEM techniques. Such detailed mineralogical analyses are not the main topic or objective of this study.

The main peak position of serpentine from Hole 778A samples ranges between 7.15 and $7.29 \AA$, with a more frequent position at 7.23-7.25 $\AA$; they show also a well-formed doublet at 2.49-2.44 $\pm 0.01 \AA$. Thus, the serpentine phase appears to be close to the lizardite type such as an $\mathrm{Al}-\mathrm{Mg}$ serpentine. The main peak intensities, as relative peak heights, may be ascribed to the relative amount of the mineral within the sample: the lowest values are for Sample 11, which is a mafic clast, and for the deepest samples in the hole.

Sepiolite is found downward in the hole, in the last four samples and in Samples 27 and 28. Palygorskite occurs only in Sample 29. These fibrous Mg-minerals have been ascribed to the alteration of serpentine minerals. In the deep-sea realm, the reactions between hydrothermal solutions, seawater, and volcanic or mafic material are often proposed for sepiolite and palygorskite genesis (Hathaway and Sachs, 1965; Bonatti and Joensuu, 1968; Bowles et al., 1971; Bonatti et al., 1983; McKenzie et al., 1989). Palygorskite, together with authigenic smectites, is known to be formed in-situ by seawater-serpentinite interactions in areas exposed to halmyrolysis for a long time (probably more than 100 $\mathrm{Ma}$ in the case of the Galicia margin, Karpoff et al., 1989).

Chlorite is found as a relatively abundant component in some samples from the bottom of the hole (Samples 25 to 28 and 31-32) and as a trace component in a few samples from the upper part. Chlorite is associated with smectites in Samples 27, 28, and 32. Chlorite is a component of the paragenesis of the serpentinites that were transformed by alteration or hydrothermal processes (Bonatti et al., 1973 ; Kimball et al.,1985).

Aragonite is present in the upper Hole 778A samples (1-13) and appears to be restricted to the lithologic Unit I. This observation confirms the previous discrimination between Units I and II and the hypothesis of Haggerty (1987) that aragonite needles develop preferentially in the uppermost levels of serpentine seamounts. Trace amounts of aragonite also occur in the foraminifer-rich serpentine microbreccia (Sample 15). The aragonite exhibits atypical X-ray diffraction patterns with a slight shift and an inversion of the intensity of two main peaks: the $3.40 \AA$ peak goes to $3.385 \AA$ and the doublet at $2.10-1.98 \AA$ goes to $2.09-1.97 \AA$ and becomes very sharp. The occurrence of aragonite is correlated 
with the high strontium to calcium ratio of the bulk rock (see below). A preliminary microprobe investigation conducted on isolated needles of aragonite indicates $1.6 \mathrm{wt} \% \mathrm{Sr}$ in aragonite. These characteristics, together with isotopic characteristics (Karpoff et al., unpubl. data), have to be compared to those of biogenic marine aragonite, which is an unstable carbonate phase at that water depth. Further analyses could specify the conditions of formation of aragonite during and after the serpentinization processes. The well-known main factors favoring aragonite precipitation are the presence of $\mathrm{Mg}$ and other cations such as $\mathrm{Sr}$ in solution, high pH and high temperature. Aragonite is described in serpentinized peridotites from fracture zones (Bonatti et al., 1980) and from the mid-Atlantic ridge axis (Bougault, pers. comm., 1991). Authigenic well-crystallized needles of aragonite were found in manganese crusts from hydrothermal deposits of an axial deep of the northern Red Sea (Karpoff et al., 1988). Aragonite is also found in mid-Atlantic ridge hydrothermal fields as the last product of the interaction between biogenic oozes and hydrothermal fluids (Lalou et al., 1990). The authigenic aragonite in serpentine sediments from Hole 778A might be a product of seawater-serpentine interactions under temperature conditions that are probably different and slightly higher than those of the bottom water.

Calcite is a minor or trace component of most of the samples from the lower part of the hole. In contrast, Fe-oxyhydroxides such as hematite and goethite are found in samples from the upper part of the section.

A mineral phase, relatively abundant in Samples 3, 4, and 21 24 , exhibits sharp peaks located at 7.97 and $4.01 \AA$ or at 7.92 and $3.98 \AA$. These patterns are attributed to magnesium hydroxycarbonates of the pyroaurite $\left[\left(\mathrm{Mg}_{6} \mathrm{Al}_{2}\right) \mathrm{OH}_{16} \mathrm{CO}_{3} \cdot n \mathrm{H}_{2} \mathrm{O}\right]$, or hydrotalcite $\left[\left(\mathrm{Mg}_{6} \mathrm{Fe}_{2}\right) \mathrm{OH}_{16} \mathrm{CO}_{3} \cdot n \mathrm{H}_{2} \mathrm{O}\right]$ groups (see Brindley and Brown, 1980). In this mineral group, which has a brucite-like structure and polytypes, cation substitutions are numerous, and the $\mathrm{CO}_{3}$ may be $\mathrm{NO}_{3}, \mathrm{SO}_{4}, \mathrm{Cl}$, or $\mathrm{ClO}_{4}$. Therefore, these diffraction patterns may be those of a chloride phase. In fact, Heling and Schwarz (this volume) attribute similar patterns (8.045 and 3.985 $\AA$ to a different oxychloride mineral, the iowaite $\left[\mathrm{Mg}_{4}(\mathrm{OH})_{8}, \mathrm{FeO}\right.$ $\mathrm{Cl} \cdot n \mathrm{H}_{2} \mathrm{O}$ ]. The complexity of the mineral family of magnesian hydroxy-carbonates, -sulfates, -chlorides, and -perchlorates involves shifts of the position of the diffraction peaks in a wide range between those of the pure end-members. Characterization of the specific hydroxycarbonates requires detailed studies (i.e., Miyata, 1975; Brindley and Kikkawa, 1979; Taylor and McKenzie, 1980; Taylor, 1984) beyond the scope of this paper. Mg-hydroxycarbonates are the product of hydrothermal alteration of mafic material (Schmitz et al., 1982) and may represent precursors of serpentine and smectite in the alteration of basaltic glasses (Crovisier et al., 1987; Crovisier, 1989, and references therein). The occurrence of this phase in Hole $778 \mathrm{~A}$ samples negatively correlates with the aragonite and $\mathrm{Fe}$-oxyhydroxides. Such a relationship may reflect various steps in the $\mathrm{Mg}-\mathrm{Ca}-\mathrm{Fe}-\mathrm{CO}_{2}-\mathrm{OH}$ system through the serpentinization sequence.

Accessory minerals include relict igneous phases as well as authigenic minerals. Plagioclases (mafic clast, Sample 15) or amphiboles and pyroxenes occur in some samples from the lower part of the section. Authigenic minerals, hydrogrossular and epidote, were identified during shipboard studies. Hydrogrossulars ranging from 100 to $500 \mathrm{~m}$ in size form aggregates and spherolites less than $1 \mathrm{~mm}$ wide that are scattered within the serpentine matrix. Microprobe analyses of hydrogrossular are reported in Table 2 .

The composition of the hydrogarnets is similar to that of hydrogrossular with high $\mathrm{Ca}, \mathrm{Si}$, and $\mathrm{Fe}$ contents. No clear evolution could be shown between the core and the rim of one large
Table 2. Microprobe analyses of hydrogarnets from Sample 125-778A-9R-1, 104-106 cm.

\begin{tabular}{lrrrrr}
\hline \multicolumn{5}{c}{ Sample Number } \\
\cline { 2 - 6 } & \multicolumn{1}{c}{1} & \multicolumn{1}{c}{2} & \multicolumn{1}{c}{3} & \multicolumn{1}{c}{4} & \multicolumn{1}{c}{5} \\
\hline $\mathrm{SiO}_{2}$ & 34.34 & 34.84 & 34.46 & 34.35 & 34.67 \\
$\mathrm{TiO}_{2}$ & 0.11 & 0.01 & 0.02 & 0.08 & 0.02 \\
$\mathrm{Al}_{2} \mathrm{O}_{3}$ & 0.35 & 0.34 & 0.35 & 0.34 & 0.38 \\
$\mathrm{FeO}^{*}$ & 27.47 & 27.93 & 28.09 & 28.04 & 27.31 \\
$\mathrm{MnO}$ & 0.00 & 0.05 & 0.00 & 0.00 & 0.01 \\
$\mathrm{MgO}$ & 0.20 & 0.24 & 0.19 & 0.19 & 0.14 \\
$\mathrm{CaO}$ & 32.49 & 32.85 & 32.45 & 32.41 & 32.88 \\
$\mathrm{Na}_{2} \mathrm{O}$ & 0.04 & 0.11 & 0.11 & 0.05 & 0.00 \\
$\mathrm{~K}_{2} \mathrm{O}$ & 0.00 & 0.03 & 0.00 & 0.01 & 0.00 \\
$\mathrm{Cr}_{2} \mathrm{O}_{3}$ & 0.07 & 0.13 & 0.06 & 0.00 & 0.05 \\
$\mathrm{sum}$ & 95.07 & 96.53 & 95.73 & 95.47 & 95.46 \\
\hline
\end{tabular}

Data in wt\%. $\mathrm{FeO}^{*}$ as total iron.

Analyses 1, 2, and 3 are from core to rim of a single crystal; analyses 4 and 5 are from the core of two different crystals (automated CAMECA SX 50 microprobe, microsonde Ouest, Brest). Analytical conditions: $15 \mathrm{kV}, 10 \mathrm{nA}$; counting time, $6 \mathrm{~s}$.

$(500 \mathrm{~m})$ crystal. Hydrogarnets are common in modern and ancient ultramafic sediments or igneous rocks that have undergone metasomatism in an ultramafic environment (rodingites). Hydrogrossular has been reported from sedimentary and igneous rocks dredged along the walls of some Atlantic fracture zones: Vema, Romanche (Honnorez and Kirst, 1975); Vema fracture zone median ridge (Lagabrielle et al., unpubl. data). Hydrogarnets are also abundant in serpentine microbreccias forming part of the initial sedimentary cover of the Chenaillet Jurassic ophiolites in the French-Italian Alps (Chéreau, pers. comm, 1990) and in many serpentinite bodies of other Alpine ophiolites.

In summary, the XRD results from bulk samples allow us to distinguish three groups among the samples collected. Samples 11,14 , and 15 , which are not typical serpentine sediments, are not considered. These groups correlate with depth down section. All samples from the three groups contain primarily serpentine minerals.

The first group, which includes Samples 1-13, is characterized by the presence of aragonite, hematite, or goethite, and halite. Few accessory minerals are present (chlorite and epidote). This assemblage implies oxidizing conditions for the chemical reactions between serpentine and seawater and/or deep fluids moving upward. These reactions appear to be characterized by the removal of calcium and strontium into an alteration byproduct, such as aragonite.

The second group, which comprises Samples 16-26 is characterized by homogeneous compositions. Hydroxycarbonates, calcite, chlorite, and hydrogrossular are present together with serpentine. These rocks have a high serpentine content and are poor in accessory minerals.

In the last group, composed of Samples 27-35, the serpentine content appears lower and correlative to the occurrence of sepiolite or palygorskite (Sample 29). Chlorite has been replaced by chlorite-smectite, interlayered, clay mineral. Traces of calcite are present. Accessory igneous minerals become more abundant. These samples have a less "ultramafic" composition as indicated by the occurrence of sepiolite with a higher $\mathrm{Si} / \mathrm{Mg}$ ratio than that of serpentine minerals $(\mathrm{Si} / \mathrm{Mg}=1)$. These characteristics could result from a high degree of alteration of serpentine, leading to the development of sepiolite and palygorskite, or from an intimate admixture of an ultramafic and a mafic source, or both. 


\section{GEOCHEMISTRY OF THE SERPENTINE SEDIMENTS}

Mineralogical studies and geochemical analyses conducted on samples from both marine and nonmarine environments indicate that differences between sedimentary rocks and their parent rocks are not always significant. Some differences are best expressed by whole-rock geochemical analyses and generally show increases in $\mathrm{CaO}, \mathrm{Al}_{2} \mathrm{O}_{3}, \mathrm{SiO}_{2}$, and $\mathrm{Fe}_{2} \mathrm{O}_{3}$ contents in sedimentary serpentinites with respect to serpentinized peridotites, and reflect nonultramafic cement of the sediment or the presence of "exotic" elements such as mafic rocks or other sedimentary rocks (Lockwood, 1971a, 1971b; Bonatti et al., 1973). Whole-rock analysis allows one to demonstrate that detrital material from various sources has been incorporated in the primary sedimentary material (Lagabrielle and Polino, 1985). We apply this method by comparing the chemical composition of the selected samples with that of their "parent" rocks, the massive serpentinized peridotites found as blocks at Sites 778 and 779 . We attempt to determine by chemical investigations whether some intervals of the drilled section show a relative heterogeneity, as suggested already by the presence of numerous exotic clasts of various origin scattered within the serpentine breccias.

\section{Major-Element Geochemistry}

The geochemical data (Table 3 ) are derived from the same set of samples studied above. Analysis of Sample 12 is presented but will not be used for discussion because of an anomalously high
$\mathrm{ZnO}$ and $\mathrm{Fe}_{2} \mathrm{O}_{3}$ content (up to $10 \% \mathrm{ZnO}$ ), probably in relation to contamination by paint particles from the ship.

$\mathrm{SiO}_{2}$ content varies from about $31 \%$ to less than $44 \%$. The highest values are found in Samples 27 to 35 from the bottom of the hole (Fig. 6). Titanium contents, not shown on Figure 6 (see Table 3), are always low, except in Sample $11\left(\mathrm{TiO}_{2}=1.30 \%\right.$, a value typical of mafic volcanic rock) and in Samples 27, 28, and 32 to 35 from the bottom of the hole where values of $0.5 \%$ to $0.84 \%$ are present. Similarly, $\mathrm{Al}_{2} \mathrm{O}_{3}$ contents are generally low, with the exception of the mafic clast (Sample 11, $\mathrm{Al}_{2} \mathrm{O}_{3}=$ $12.88 \%$ ), Sample 15 and Samples $27-28$ and 32 to 35 from the lower part of the hole. $\mathrm{Fe}_{2} \mathrm{O}_{3}$ contents range from $5.84 \%$ to $10.31 \%$, the highest values are found in Samples 11, 27, 28, and 32 to 35 . $\mathrm{MgO}$ contents are similar to $\mathrm{SiO}_{2}$ contents, except in Samples 11 (mafic clast), 15,27 to 28 , and 32 to 35 . $\mathrm{CaO}$ contents correlate with alumina content, with the exception of the upper samples $(1,2$, and 6 to 10$)$, where $\mathrm{CaO}$ contents may vary from $4.08 \%$ to $9.34 \%$ (Fig. 6 ). $\mathrm{SiO}_{2} / \mathrm{MgO}$ ratio for all the samples is remarkably constant (very close to 1) except for a group of samples from the bottom of the hole (27 to 35) (Fig. 7). Similarly, the massive serpentinized peridotites recovered as clasts in Holes $778 \mathrm{~A}$ (see, for example, analysis 14) and 779A also show a constant $\mathrm{SiO}_{2} / \mathrm{MgO}$ ratio with values close to 1 (Fig. 8) (Fryer, Pearce, Stokking, et al., 1990).

LOI (loss on ignition) values vary from $10 \%$ to nearly $20 \%$, which are values commonly encountered in highly serpentinized rocks. As shown in the diagram in Figure 9, LOI and $\mathrm{SiO}_{2}$ contents present a clear negative correlation. This correlation is similar to that shown by the clasts of massive serpentinized peridotites from

Table 3. Major-element concentrations in serpentine sediments.

\begin{tabular}{|c|c|c|c|c|c|c|c|c|c|c|c|c|c|c|c|c|c|c|c|c|c|c|c|}
\hline \multicolumn{24}{|c|}{ Sample Number } \\
\hline & 1 & 2 & 3 & 4 & 5 & 6 & 7 & 8 & 9 & 10 & 11 & 12 & 13 & 14 & 15 & 16 & 17 & 18 & 19 & 20 & 21 & 22 & 23 \\
\hline $\mathrm{SiO}_{2}$ & 33.20 & 34.50 & 36.00 & 36.00 & 37.50 & 34.50 & 34.00 & 32.50 & 31.20 & 32.80 & 35.20 & 24.00 & 35.50 & 36.40 & 37.80 & 37.90 & 37.80 & 39.50 & 39.20 & 38.40 & 38.15 & 38.15 & 37.00 \\
\hline $\mathrm{To}_{2}$ & 0.03 & 0.00 & 0.02 & 0.02 & 0.02 & 0.03 & 0.02 & 0.01 & 0.02 & 0.18 & 1.30 & 0.05 & 0.08 & 0.00 & 0.19 & 0.00 & 0.00 & 0.19 & 0.02 & 0.00 & 0.00 & 0.00 & 0.00 \\
\hline $\mathrm{Al}_{2} \mathrm{O}_{3}$ & 0.65 & 0.09 & 0.62 & 0.74 & 1.09 & 0.69 & 0.62 & 0.54 & 0.64 & 2.41 & 12.88 & 0.57 & 2.29 & 0.81 & 4.58 & 0.65 & 0.64 & 1.42 & 0.88 & 0.67 & 0.70 & 0.48 & 0.46 \\
\hline $\mathrm{Fe}_{2} \mathrm{O}, \mathrm{T}$ & 5.84 & 7.19 & 6.73 & 6.85 & 6.75 & 6.15 & 6.05 & 5.90 & 6.07 & 6.66 & 10.31 & 13.66 & 7.14 & 7.22 & 7.46 & 6.75 & 6.96 & 6.25 & 6.88 & 7.13 & 6.80 & 6.35 & 6.76 \\
\hline $\mathrm{MnO}$ & 0.11 & 0.08 & 0.09 & 0.09 & 0.11 & 0.12 & 0.14 & 0.11 & 0.13 & 0.14 & 0.19 & 0.15 & 0.12 & 0.17 & 0.13 & 0.09 & 0.11 & 0.16 & 0.10 & 0.10 & 0.11 & 0.09 & 0.10 \\
\hline $\mathrm{MgO}$ & 21.22 & 34.60 & 36.65 & 37.34 & 36.70 & 32.45 & 32.60 & 31.82 & 31.70 & 30.17 & 17.20 & 20.35 & 34.34 & 38.60 & 27.00 & 39.22 & 38.75 & 37.85 & 38.10 & 38.00 & 38.15 & 38.15 & 39.00 \\
\hline $\mathrm{CaO}$ & 8.89 & 4.08 & 1.40 & 0.78 & 1.21 & 6.54 & 7.16 & 8.80 & 9.34 & 8.88 & 11.49 & 5.61 & 2.03 & 0.15 & 6.55 & 0.17 & 0.11 & 0.33 & 0.59 & 1.26 & 0.74 & 1.33 & 1.03 \\
\hline $\mathrm{Na}_{2} \mathrm{O}$ & 0.45 & 0.65 & 0.63 & 0.51 & 0.79 & 0.71 & 0.67 & 0.59 & 0.40 & 0.72 & 0.54 & 0.24 & 0.94 & 0.04 & 1.02 & 0.23 & 0.13 & 0.19 & 0.30 & 0.13 & 0.13 & 0.13 & 0.14 \\
\hline $\mathrm{K}, \mathrm{O}$ & 0.02 & 0.02 & 0.03 & 0.02 & 0.05 & 0.04 & 0.03 & 0.01 & 0.10 & 0.05 & 0.20 & 0.05 & 0.05 & 0.05 & 0.05 & 0.10 & 0.00 & 0.00 & 0.00 & 0.00 & 0.00 & 0.00 & 0.00 \\
\hline $\mathrm{P}_{2} \mathrm{O}_{4}$ & 0.05 & 0.05 & 0.00 & 0.05 & 0.05 & 0.00 & 0.00 & 0.05 & 0.02 & 0.02 & 0.05 & 0.00 & 0.09 & 0.00 & 0.17 & 0.01 & 0.02 & 0.05 & 0.02 & 0.02 & 0.05 & 0.02 & 0.05 \\
\hline LO.I. & 19.55 & 17.96 & 17.37 & 16.74 & 15.59 & 18.11 & 18.58 & 19.23 & 19.50 & 17.41 & 10.24 & 24.00 & 16.24 & 16.62 & 14.41 & 14.96 & 14.73 & 13.55 & 12.97 & 19.76 & 14.65 & 15.01 & 15.14 \\
\hline Sum & 100.01 & 99.17 & 99.54 & 99.14 & 99.86 & 99.34 & 99.87 & 99.56 & 99.12 & 99.44 & 99.60 & 88.68 & 98.82 & 100.06 & 99.36 & 100.08 & 99.25 & 99.49 & 99.06 & 99.47 & 99.48 & 99.71 & 99.68 \\
\hline
\end{tabular}

Table 3 (continued).

\begin{tabular}{|c|c|c|c|c|c|c|c|c|c|c|c|c|}
\hline & \multirow[b]{2}{*}{24} & \multirow[b]{2}{*}{25} & \multirow[b]{2}{*}{26} & \multicolumn{9}{|c|}{ Sample Number } \\
\hline & & & & 27 & 28 & 29 & 30 & 31 & 32 & 33 & 34 & 35 \\
\hline $\mathrm{SiO}_{2}$ & 38.00 & 38.60 & 38.45 & 42.10 & 41.00 & 42.70 & 40.40 & 39.00 & 43.80 & 42.00 & 42.70 & 441.00 \\
\hline $\mathrm{TO}_{2}^{2}$ & 0.00 & 0.00 & 0.00 & 0.50 & 0.31 & 0.00 & 0.00 & 0.00 & 0.80 & 0.16 & 0.44 & 0.84 \\
\hline $\mathrm{Al}_{2} \mathrm{O}_{3}$ & 0.54 & 0.37 & 0.45 & 5.43 & 3.62 & 0.85 & 0.59 & 0.55 & 6.25 & 3.18 & 7.08 & 5.80 \\
\hline $\mathrm{Fe}_{2} \mathrm{O}_{3} \mathrm{~T}$ & 6.91 & 6.72 & 6.17 & 9.87 & 8.50 & 7.26 & 7.39 & 7.39 & 10.00 & 7.54 & 8.21 & 7.75 \\
\hline $\mathrm{MnO}$ & 0.09 & 0.09 & 0.09 & 0.15 & 0.15 & 0.11 & 0.08 & 0.08 & 0.18 & 0.17 & 0.18 & 0.17 \\
\hline $\mathrm{MgO}$ & 37.50 & $\mathbf{3 8 . 7 0}$ & 38.40 & 24.93 & 30.44 & 34.85 & 38.25 & 30.85 & 21.88 & 30.50 & 23.95 & 28.00 \\
\hline $\mathrm{CaO}$ & 1,75 & 0.56 & 0.90 & 3.75 & 2.69 & 0.27 & 0.12 & 0.34 & 5.19 & 1.41 & 1.86 & 2.20 \\
\hline $\mathrm{Na}_{2} \mathrm{O}$ & 0.27 & 0.31 & 0.25 & 1.66 & 0.98 & 0.37 & 0.23 & 0.18 & 1.74 & 1.27 & 2.34 & 1.35 \\
\hline $\mathrm{K}_{2} \mathrm{O}$ & 0.00 & 0.01 & 0.00 & 0.03 & 0.01 & 0.01 & 0.00 & 0.00 & 0.02 & 0.06 & 0.07 & 0.01 \\
\hline $\mathrm{P}_{2} \mathrm{O}_{3}$ & 0.02 & 0.02 & 0.01 & 0.05 & 0.05 & 0.05 & 0.02 & 0.02 & 0.08 & 0.05 & 0.25 & 0.10 \\
\hline Lo. & 14.23 & 14.46 & 14.92 & 10.93 & 12.04 & 13.36 & 12.75 & 12.88 & 9.67 & 12.32 & 12.32 & 12.21 \\
\hline Sum & 99.31 & 99.84 & 99.64 & 99.40 & 99.79 & 98.83 & 99.83 & 99.29 & 99.61 & 98.66 & 99.40 & 99.43 \\
\hline
\end{tabular}

Data (in w1\% oxides) are from whole-rock analyses by emission and atomic absorption spectrophotometry. L.O.L. is loss on ignition between $25^{\circ}$ and $1050^{\circ} \mathrm{C}$. 


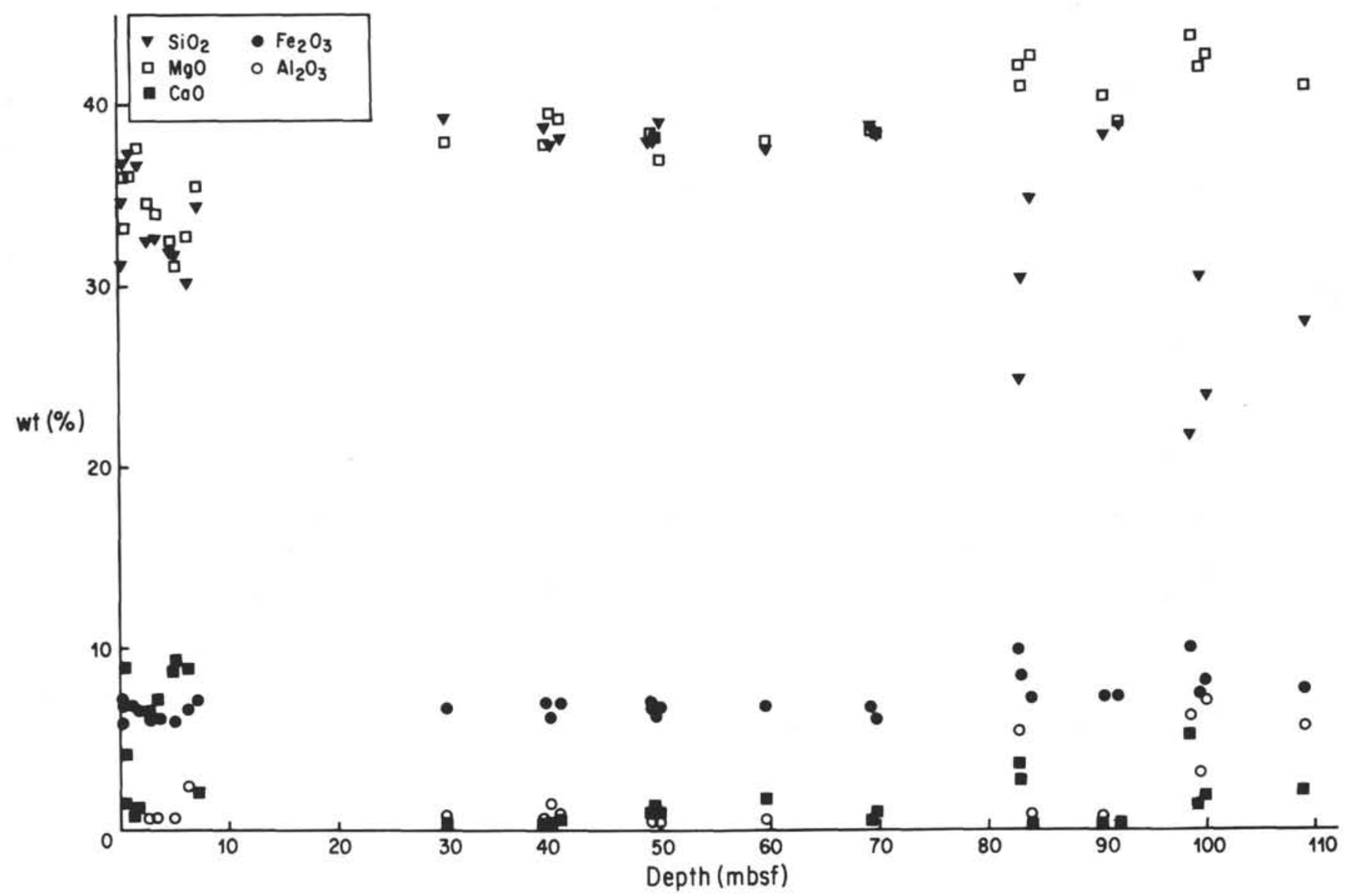

Figure 6. Main major-element $\left(\mathrm{SiO}_{2}, \mathrm{Al}_{2} \mathrm{O}_{3}, \mathrm{Fe}_{2} \mathrm{O}_{3}, \mathrm{MgO}\right.$, and $\left.\mathrm{CaO}\right)$ composition of analyzed serpentine microbreccias, sand, and silt from $\mathrm{Hole} 778 \mathrm{~A}$, plotted vs. depth. Compositions of Samples 11,12, 14, and 15 are not represented.

Sites 778 and 779. Three groups can be distinguished based upon the LOI values of the selected samples (Fig. 10). The upper samples (1-10: Group A) show the highest LOI values. These values are somewhat higher than in massive serpentinized igneous peridotites from Conical Seamount, where LOI values do not exceed $18 \%$ (Fryer, Pearce, Stokking, et al., 1990). These samples also present the highest $\mathrm{CaO}$ contents and are characterized by the occurrence of aragonite needles. Therefore, the high LOI values in these samples can be inferred both to loss of water linked to serpentine minerals and to loss of $\mathrm{CO}_{2}$ from carbonates. The second group (Samples 16-26: Group B) is characterized by homogeneous values (average 14\%) typical of massive serpentinized rocks. The third group (analyses 27 to 35 : Group C) shows lower LOI values (less than $13 \%$ ) in relation to higher $\mathrm{SiO}_{2}, \mathrm{Fe}_{2} \mathrm{O}_{3}$, $\mathrm{Al}_{2} \mathrm{O}_{3}$, and $\mathrm{CaO}$ contents and lower $\mathrm{MgO}$ contents. We may conclude that the lower LOI values that characterize this group are related to a lower amount of serpentine present in the samples. This confirms the conclusions of the mineralogical investigation presented above.

Discriminations based upon LOI values can be retrieved using other major elements. In the $\mathrm{SiO}_{2}$ vs. MgO diagram, three fields corresponding to the three different groups of composition defined above can be distinguished (Fig. 11). Field A includes analyses that plot along the line $\mathrm{MgO}=\mathrm{SiO}_{2}$, with low silica and magnesium contents. Field $\mathrm{B}$ contains a group of almost uniform $\mathrm{SiO}_{2}$ vs $\mathrm{MgO}$, with relatively high $\mathrm{Mg}$ and $\mathrm{Si}$ content. These analyses plot in the field of massive serpentinized peridotites from Conical Seamount. Analyses from Group C are characterized by high $\mathrm{SiO}_{2}$ contents and low to very low $\mathrm{MgO}$ contents, with a negative $\mathrm{SiO}_{2} / \mathrm{MgO}$ correlation.

The behavior of major elements with respect to silica and magnesium contents can be visualized using a series of diagrams showing the ratio $\mathrm{SiO}_{2} / \mathrm{MgO}$ vs. other major- element contents (Fig. 12). These diagrams allow one to discriminate clearly the analyses of Group C. This group of samples is characterized by a positive correlation between $\mathrm{SiO}_{2} / \mathrm{MgO}$ and $\mathrm{Al}_{2} \mathrm{O}_{3}, \mathrm{CaO}, \mathrm{Fe}_{2} \mathrm{O}_{3}$, $\mathrm{Na}_{2} \mathrm{O}, \mathrm{TiO}_{2}$, and $\mathrm{MnO}$. This confirms that the silica enrichment and the low $\mathrm{MgO}$ content that characterize this group of samples are linked mainly to aluminum, calcium, iron, and titanium enrichment. These geochemical characteristics can be explained by the presence of mafic components (isolated minerals or lithic fragments) within the ultramafic sediments. In the $\mathrm{SiO}_{2} / \mathrm{MgO}$ vs. $\mathrm{Al}_{2} \mathrm{O}_{3}, \mathrm{Fe}_{2} \mathrm{O}_{3}, \mathrm{Na}_{2} \mathrm{O}, \mathrm{TiO}_{2}$, and $\mathrm{MnO}$ diagrams, analyses from Groups $\mathrm{A}$ and $\mathrm{B}$ plot in a restricted field with $\mathrm{SiO}_{2} / \mathrm{MgO}$ values close to 1 .

In the $\mathrm{SiO}_{2} / \mathrm{MgO}$ vs. $\mathrm{CaO}$ diagram, analyses from Group A plot along a subhorizontal line, indicating that samples show calcium enrichment without modification of the $\mathrm{SiO}_{2} / \mathrm{MgO}$ ratio; in other words, calcium is simply added to the ultramafic component. Such a characteristic is linked to the occurrence of aragonite crystals within the serpentine muds. $\mathrm{K}_{2} \mathrm{O}$ content is relatively high in samples from Groups $\mathrm{A}$ and $\mathrm{C}$, probably in relation to seawater interactions (Group A) and to mafic contribution (Group C). In contrast to the results presented here, analyses of massive, serpentinized peridotite clasts recovered at Sites 778 and 779 (see tables from site reports, for Sites 778 and 779, in Fryer, Pearce, Stok- 


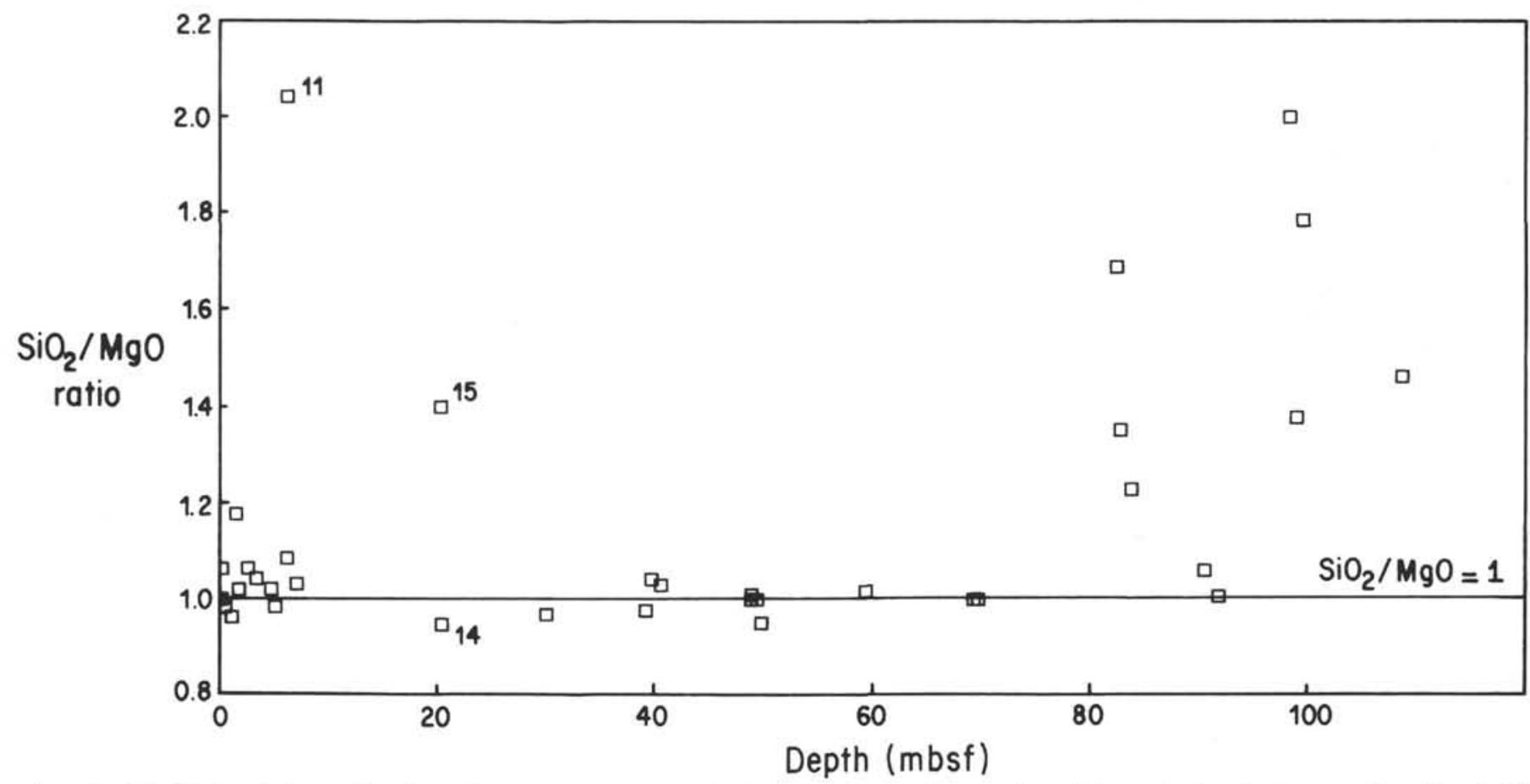

Figure 7. $\mathrm{SiO}_{2} / \mathrm{MgO}$ ratio for analyzed samples vs. depth in Hole 778A. Sample 11 is a soft green clast with a mafic chemical composition; Sample 14 is a hard clast of massive serpentinized peridotite, and Sample 15 is a pebble of consolidated, foraminifer-rich serpentine microbreccia.

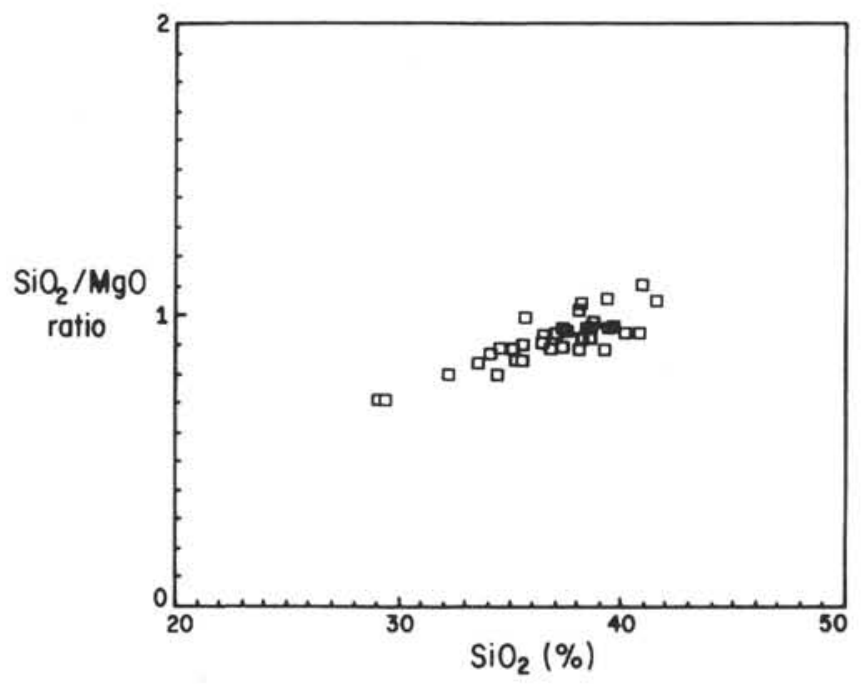

Figure $8 . \mathrm{SiO}_{2} / \mathrm{MgO}$ ratio vs. $\mathrm{SiO}_{2}$ for serpentinized peridotites recovered from Conical Seamount Sites 778 and 779. Analyses are from site reports for Sites 778 and 779 (Fryer, Pearce, Stokking, et al., 1990).

king, et al., 1990), do not show significant major-element content variations $\left(\mathrm{Al}_{2} \mathrm{O}_{3}\right.$ content is lower than $1.1 \%, \mathrm{Fe}_{2} \mathrm{O}_{3}$ content ranges from $5.6 \%$ to $9.2 \%$ and $\mathrm{CaO}$ content is generally lower than $1 \%)$.

\section{Trace-Element Geochemistry}

Trace-element concentrations are reported in Table 4. Chromium and nickel concentrations in the serpentine sediments are high, but are lower than in massive serpentinized peridotites (Fig. 13 ), indicating that $\mathrm{Cr}$-bearing minerals (such as spinels) have not been concentrated within the sediments. Barium is high in some samples from the upper part of the hole. Vanadium correlates with titanium. Strontium is high in Samples 1-15 (Group A) and

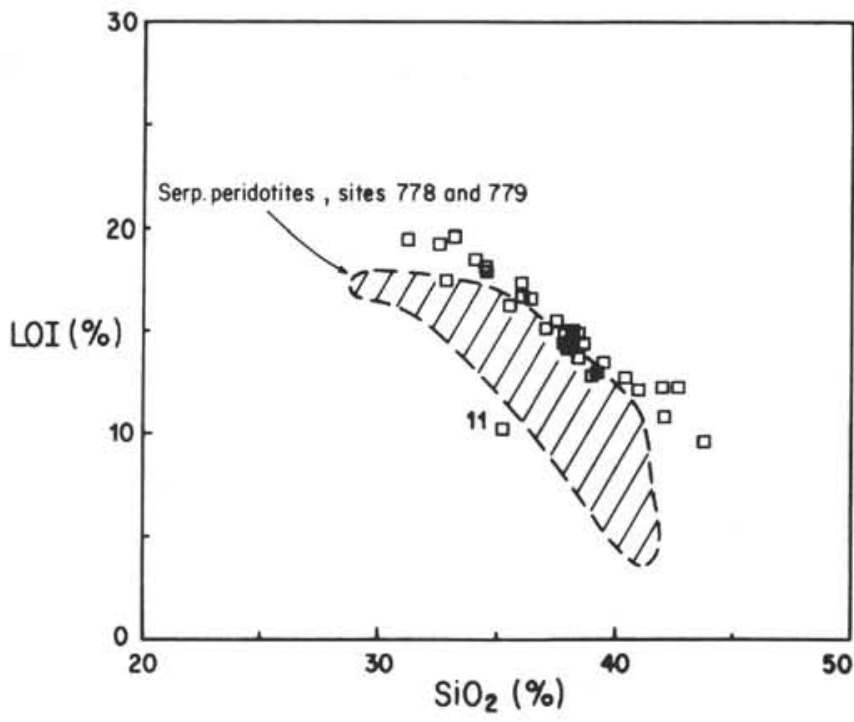

Figure 9. LOI vs. $\mathrm{SiO}_{2}$ diagram for analyzed samples at Site 778. Composition of clasts of serpentinized peridotites recovered from Conical Seamount at Sites 778 and 779 are also reported (analyses from site reports for Sites 778 and 779; Fryer, Pearce, Stokking, et al., 1990). The position of Sample 11 (mafic clast) is indicated.

relatively high in Samples 27-35 (Group C). Occurrence of high strontium values in the upper part of the hole is directly related to the presence of aragonite, as shown by the $\mathrm{Sr} / \mathrm{CaO}$ correlation in the diagram of Figure 14. Compositions of Samples 1- 10 (Group A), characterized by remarkably high $\mathrm{Sr}$ concentrations, plot along a line different from the classical $\mathrm{Sr} / \mathrm{Ca}$ ratio of calcareous oozes (Karpoff, 1989). This suggests that strontium was concentrated from seawater during the precipitation of aragonite. The diagrams in Figure 15 show a negative correlation between $\mathrm{Al}_{2} \mathrm{O}_{3}$ content and chromium and nickel concentrations and confirm the 


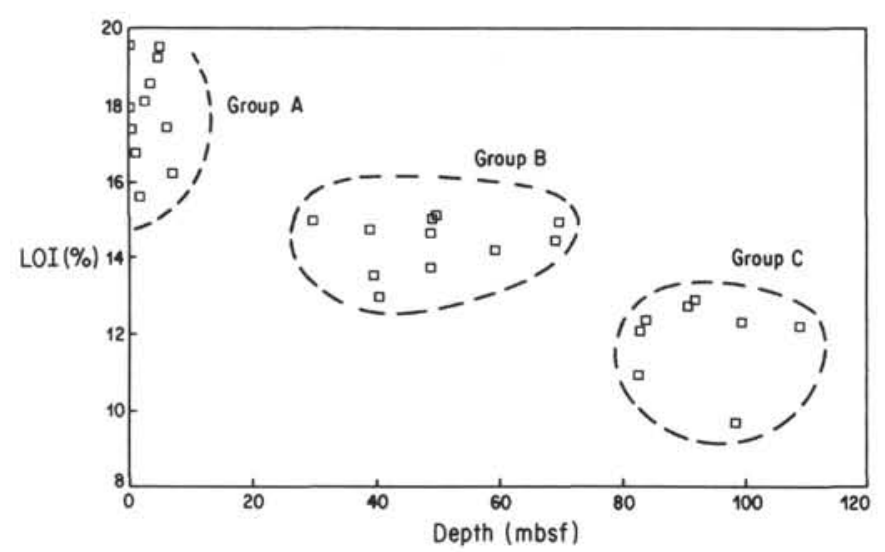

Figure 10. LOI vs. depth diagram for the analyzed samples from Hole 778A for Groups A (Samples 1-10), B (Samples 16-26), and C (Samples 27-35).

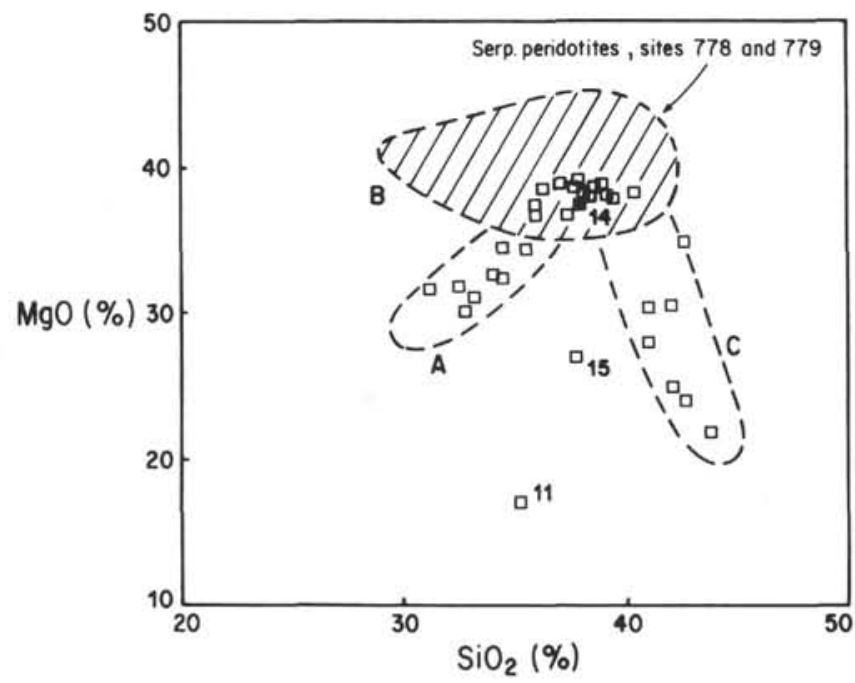

Figure 11. Composition of the analyzed samples plotted in the $\mathrm{MgO} / \mathrm{SiO}_{2}$ diagram. Groups A, B, and C, defined in Figure 10, can be seen. Compositions of clasts of serpentinized peridotites recovered from the Conical Seamount at Sites 778 and 779 fall in a restricted field (analyses from site reports for Sites 778 and 779; Fryer, Pearce, Stokking, et al., 1990). Analyses of geochemical Group B samples fall in this field.

abundance of "mafic" elements (a characteristic of Group C samples) correlates with a lower concentration in trace elements from an ultramafic source. Finally, the third group of analyses (recognized on the basis of high $\mathrm{Al}_{2} \mathrm{O}_{3}, \mathrm{CaO}, \mathrm{Fe}_{2} \mathrm{O}_{3}, \mathrm{TiO}_{2}$, etc.) contents can also be discriminated on the basis of trace-element concentrations.

\section{SUMMARY AND CONCLUSIONS}

The results of both bulk-rock mineralogical (XRD) and geochemical investigations yielded remarkably similar conclusions. Both allow one to distinguish three groups among the selected samples. These groups correspond to three stratigraphic intervals present along the drilled section. Group A contains the upper samples, found in Cores 125-778A-1R and 125-778A-2R (lithologic Unit I). They consist of clay- and silt-sized, poorly consolidated serpentinite with hard-rock clasts (serpentinized peridotites, metabasalts). They are characterized by the following mineralogical assemblage: serpentine, $\mathrm{Fe}$-oxides and hydroxides, aragonite, and halite. Geochemically, they show variable $\mathrm{SiO}_{2}$ and $\mathrm{MgO}$ contents, but are characterized by a $\mathrm{SiO}_{2} / \mathrm{MgO}$ ratio close to 1 . $\mathrm{CaO}$ content is high in relation to development of aragonite, explaining the low $\mathrm{Si}$ and $\mathrm{Mg}$ concentrations. $\mathrm{Al}_{2} \mathrm{O}_{3}$ content is low. Relatively high $\mathrm{K}_{2} \mathrm{O}, \mathrm{Na}_{2} \mathrm{O}$, and $\mathrm{Sr}$ contents are present, presumably related to interactions with seawater.

Group B contains samples showing homogeneous chemical and mineralogical compositions. Samples from this group are found in Cores 125-778A-5R - 125-778A-9R (lithologic Unit II); that is from about 30 to 77 mbsf. They consist of serpentinite microbreccias that exhibit frequent shear structures and hard-rock clasts (serpentinized peridotites, metabasalts, one possible chert fragment). Their mineralogy is characterized by the presence of serpentine and authigenic minerals: hydroxycarbonates and hydrogrossular. Calcite and chlorite are also present, but all the samples lack aragonite. They show chemical compositions remarkably similar to compositions of their parent rocks. Contents of major- and trace-elements are indeed similar to those of serpentinized peridotites found as hard-rock clasts in Sites 778 and 779.

Group C contains samples present in Cores 125-778A-11R, $125-778 \mathrm{~A}-12 \mathrm{R}$, and $125-778 \mathrm{~A}-13 \mathrm{R}$. Here, the silt- and sand-sized serpentine sediments and microbreccia are locally rich in red clasts, probably strongly altered (oxidized?) mafic fragments. Intervals having clasts of more diverse origin than those in the upper section were recovered. Clast lithology includes serpentinized peridotites, metabasalts, metavolcaniclastite, meta-olivine gabbro, and amphibolite sandstone. The mineralogy and geochemistry are a reflection of these characteristics. Serpentine content of the samples is lower than in previous groups. Correlatively, sepiolite, palygorskite, and chlorite-smectite are mineral phases present in the analyzed samples. Accessory igneous minerals (amphiboles, pyroxenes, hematite) also were found. The chemical compositions of most of the samples from this group are not similar to that of massive serpentinized peridotites. The main differences are higher $\mathrm{SiO}_{2}, \mathrm{CaO}, \mathrm{TiO}_{2}$, and $\mathrm{Al}_{2} \mathrm{O}_{3}$ contents; a $\mathrm{SiO}_{2} / \mathrm{MgO}$ ratio greater than 1 ; a positive correlation between $\mathrm{Al}_{2} \mathrm{O}_{3}$ and $\mathrm{CaO}, \mathrm{Fe}_{2} \mathrm{O}_{3}, \mathrm{TiO}_{2}, \mathrm{Na}_{2} \mathrm{O}, \mathrm{MnO}, \mathrm{K}_{2} \mathrm{O}$; and a negative correlation among $\mathrm{Al}_{2} \mathrm{O}_{3}, \mathrm{MgO}, \mathrm{Cr}$, and $\mathrm{Ni}$.

According to these results, the stratigraphy of Site 778 can be completed by adjunction of two subunits within Unit II. Subunit IIA should correspond to rocks from Group B defined here, Subunit IIB should include Group C samples.

Group B samples can be interpreted as pure sedimentary serpentinites with composition strictly reflecting the composition of their parent rocks (Fig. 16). Samples from Group A resemble Group B samples, but are characterized by development of aragonite and iron oxides. They can be regarded as pure sedimentary serpentinites that underwent further evolution in the upper level of the seamount, where they have been (and are presently) subjected to interactions with seawater and possible deep fluids. Analyses of Group C samples differ from analyses of the parent rocks. The corresponding samples can be considered as the result of the admixture of fine-grained ultramafic sediments with mafic components: lithic fragments of strongly altered igneous rocks or isolated minerals (pyroxenes, amphiboles, and plagioclases). The mafic contribution can be estimated assuming, for example, that the total titanium originated from mafic volcanic clasts with an average of $1.6 \% \mathrm{TiO}_{2}$. In Sample 32, where $\mathrm{TiO}_{2}$ content is $0.8 \%$, the mafic contribution should be $50 \%$ by volume, but local concentration of titanium-bearing minerals within some samples must be considered. Other estimates, based upon other elements, lead to estimated values of about $15 \%$ for the mafic contribution. The polymict character of the sedimentary serpentine-rich formations drilled at Site 778 is clearly evidenced at the scale of the entire 

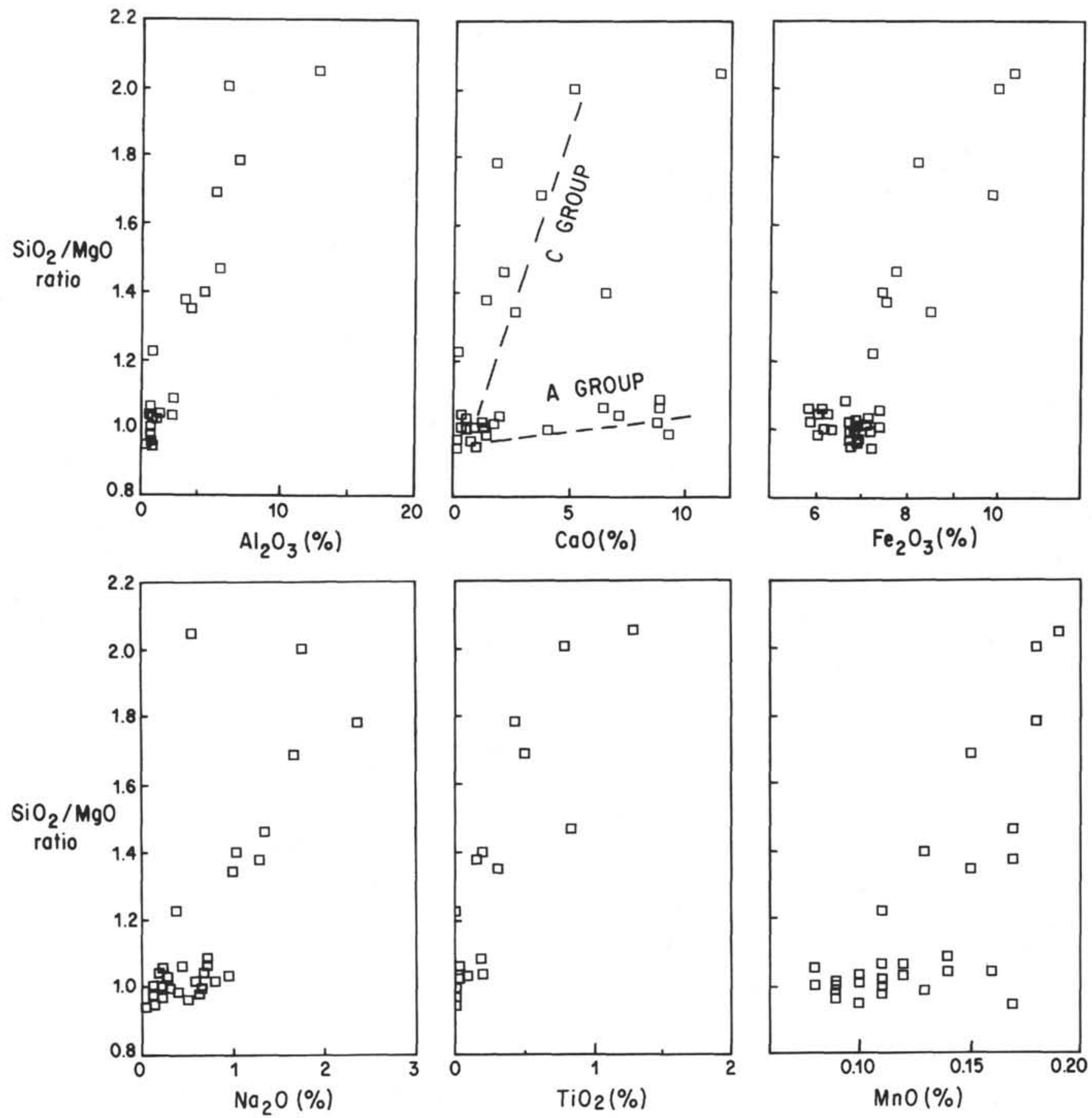

Figure 12. Discrimination diagrams for the analyzed samples using $\mathrm{SiO}_{2} / \mathrm{MgO}$ ratio vs. $\mathrm{Al}_{2} \mathrm{O}_{3}, \mathrm{CaO}_{,} \mathrm{Fe}_{2} \mathrm{O}_{3}, \mathrm{Na}_{2} \mathrm{O}$, TiO $\mathrm{CaO}$ diagram two trends of composition (corresponding to Groups $\mathrm{A}$ and $\mathrm{C}$ samples) can be distinguished.

section, when considering the various lithologies of the clasts incorporated within the serpentine. "Exotic" blocks include mantle-derived rocks, mafic plutonic and volcanic rocks of diverse geochemical affinities, sedimentary rocks, and volcano-sedimentary rocks. Our study confirms that this polymict character can be determined locally at a much smaller scale.

These data cannot help one to determine definitively whether the serpentine material now exposed on the flank of the seamount originated from a deep conduit that crosscuts the forearc basement or from a shallower source, such as an ultramafic basement exposed over a broad region by large-scale normal faulting in the forearc (Leg 125 Scientific Party, 1989). But some new constraints must now be considered in any model accounting for the superficial evolution of the flanks of Conical Seamount.

A major limit is present between Subunits IIA and IIB that corresponds to the boundary between lower, ultramafic sediment showing a significant contribution from a fine-grained mafic source and upper, pure, fine-grained serpentine. It is possible that rocks from Subunit IIB underwent long periods of brecciation, reworking, and resedimentation, permitting a significant mixing 
Table 4. Trace-element concentrations in serpentine sediments.

\begin{tabular}{|c|c|c|c|c|c|c|c|c|c|c|c|c|c|c|c|c|c|c|c|c|c|c|c|}
\hline & \multicolumn{23}{|c|}{ Sample Number } \\
\hline & 1 & 2 & 3 & 4 & 5 & 6 & 7 & 8 & 9 & 10 & 11 & 12 & 13 & 14 & 15 & 16 & 17 & 18 & 19 & 20 & 21 & 22 & 23 \\
\hline $\mathrm{Li}$ & 4.5 & 1.3 & 1.8 & 2.7 & 3.3 & 4.7 & 4.7 & 4.5 & 4.7 & 6.0 & 17.0 & 108 & 5.6 & 9.0 & 7,4 & 0.0 & 0.2 & 4.7 & 3.6 & 0.0 & 0.0 & 0.0 & 0.0 \\
\hline $\mathbf{R b}$ & 2 & 2 & 2 & 2 & 2 & 2 & 2 & 2 & 2 & 2 & 2 & 3 & 2 & 2 & 5 & 2 & 2 & 2 & 2 & 2 & 2 & 2 & 2 \\
\hline $\mathrm{Sr}$ & 1345 & 735 & 177 & 44 & 86 & 950 & 1055 & 1320 & 1330 & 1085 & 77 & 900 & 143 & 6 & 394 & 15 & 9 & 10 & 9 & 7 & 6 & 6 & 5 \\
\hline $\mathrm{Ba}$ & 73 & 15 & 15 & 15 & 15 & 15 & 15 & 15 & 15 & 15 & 30 & 230 & 30 & 15 & 78 & 15 & 15 & 15 & 15 & 15 & 15 & 15 & 15 \\
\hline $\mathrm{v}$ & 15 & 15 & 15 & 15 & 20 & 15 & 15 & 15 & 15 & 20 & 155 & 30 & 25 & 15 & 54 & 15 & 15 & 25 & 20 & 20 & 15 & 15 & 15 \\
\hline $\mathrm{Cr}$ & 1220 & 414 & 1390 & 1500 & 1450 & 1230 & 1245 & 1100 & 1305 & 1190 & 520 & 1390 & 1440 & 2200 & 1110 & 1550 & 3310 & 1115 & 1850 & 1535 & 2775 & 1880 & 1905 \\
\hline Co & 81 & 102 & 88 & 90 & 93 & 84 & 83 & 67 & 81 & 75 & 48 & 63 & 97 & 63 & 81 & 95 & 100 & 88 & 85 & 84 & 98 & 88 & 92 \\
\hline $\mathrm{Ni}$ & 1770 & 2125 & 1900 & 1920 & 1960 & 1825 & 1800 & 1750 & 1750 & 1700 & 1085 & 1210 & 1920 & 1920 & 1300 & 1920 & 2710 & 1590 & 1960 & 1350 & 2310 & 1860 & 2020 \\
\hline $\mathrm{Cu}$ & 61 & 112 & 57 & 51 & 40 & 74 & 69 & 60 & 40 & 38 & 32 & 296 & 45 & 16 & 71 & 38 & 17 & 18 & 15 & 29 & 36 & 23 & 46 \\
\hline $\mathrm{Zn}$ & 97 & 143 & 53 & 38 & 35 & 55 & 58 & 134 & 123 & 65 & 84 & * & 62 & 47 & 52 & 56 & 43 & 37 & 38 & 33 & 35 & 35 & 35 \\
\hline
\end{tabular}

Table 4 (continued).

\begin{tabular}{|c|c|c|c|c|c|c|c|c|c|c|c|c|}
\hline & \multicolumn{12}{|c|}{ Sample Number } \\
\hline & 24 & 25 & 26 & 27 & 28 & 29 & 30 & 31 & 32 & 33 & 34 & 35 \\
\hline Li & 0.0 & 0.0 & 0.0 & 12.3 & 16.3 & 17.2 & 1.5 & 0.9 & 6.5 & 10.3 & 11.8 & 19.0 \\
\hline $\mathrm{Rb}$ & 2 & 2 & 2 & 2 & 2 & 2 & 2 & 2 & 2 & 2 & 2 & 2 \\
\hline $\mathrm{Sr}$ & 17 & 3 & 5 & 64 & 52 & 37 & 15 & 15 & 60 & 69 & 92 & 74 \\
\hline $\mathrm{Ba}$ & 15 & 15 & 15 & 15 & 15 & 15 & 15 & 15 & 16 & 15 & 15 & 15 \\
\hline $\mathrm{v}$ & 15 & 15 & 15 & 100 & 58 & 15 & 15 & 20 & 140 & 20 & 25 & 134 \\
\hline $\mathrm{Cr}$ & 1660 & 1180 & 1260 & 1185 & 915 & 1235 & 1600 & 1900 & 510 & 1950 & 343 & 515 \\
\hline Co & 87 & 74 & 71 & 110 & 98 & 126 & 92 & 97 & 56 & 167 & 54 & 46 \\
\hline $\mathrm{Ni}$ & 1630 & 1410 & 1365 & 2250 & 1880 & 2060 & 2090 & 1845 & 795 & 2065 & 1040 & 960 \\
\hline $\mathrm{Cu}$ & 40 & 40 & 34 & 57 & $\begin{array}{r}500 \\
50\end{array}$ & 28 & 28 & 16 & 52 & 45 & 103 & 53 \\
\hline $\mathrm{Zn}$ & 31 & 27 & 28 & 63 & 51 & 37 & 31 & 34 & 73 & 54 & 80 & 58 \\
\hline
\end{tabular}

* $\mathrm{ZnO}=10.20 \%$ between $25^{\circ}$ and $1050^{\circ} \mathrm{C}$ 


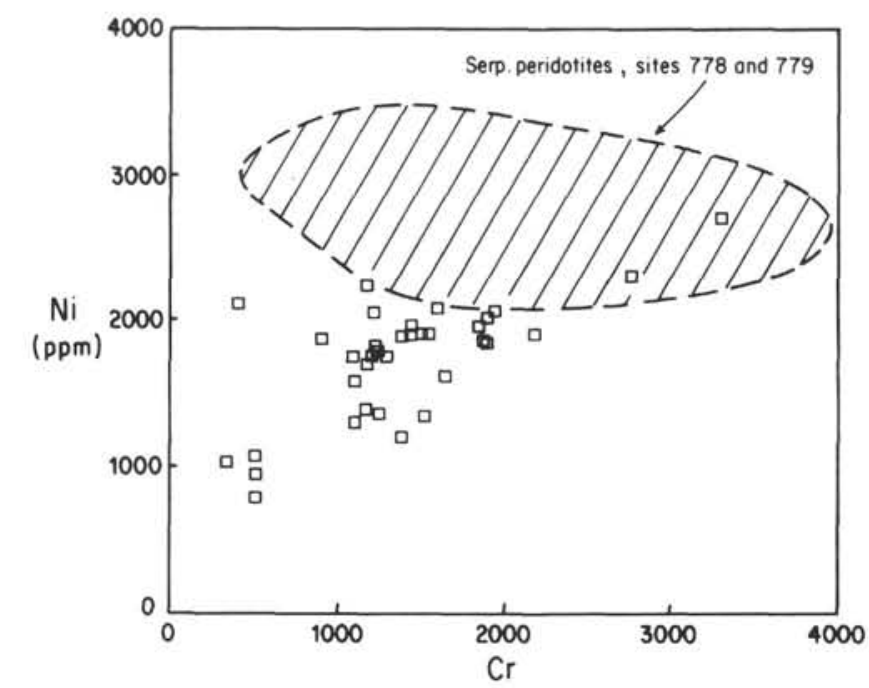

Figure 13. Ni vs. Cr diagram for the analyzed samples. Compositions of clasts of serpentinized peridotites recovered from Sites 778 and 779 fall in a separate field (analyses from site reports for Sites 778 and 779; Fryer, Pearce, Stokking, et al., 1990).

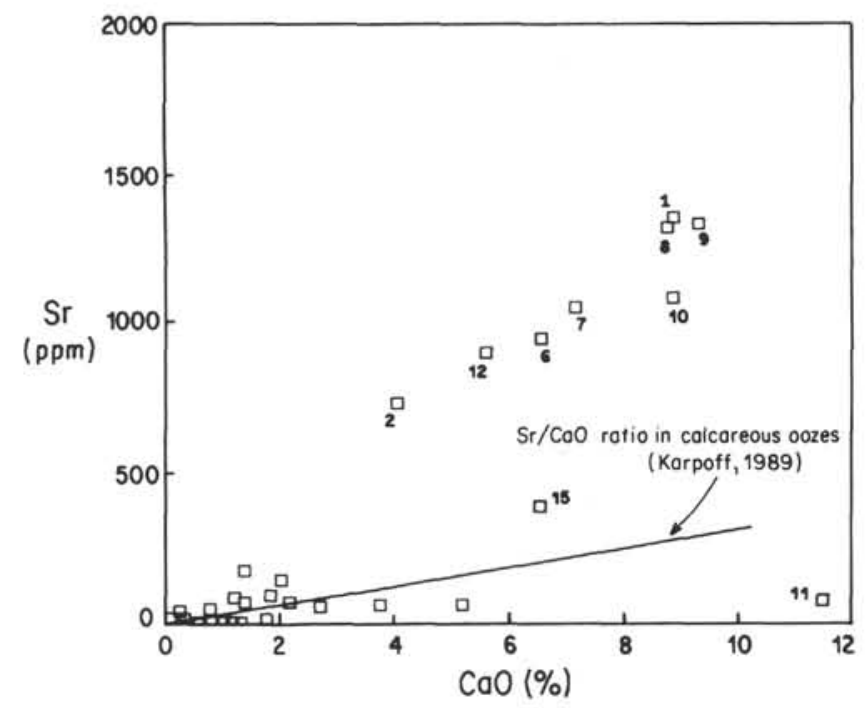

Figure 14. Sr vs. CaO diagram for the analyzed samples from Hole 778A. Note that values for Samples 1 to 10 fall along a different line from the average $\mathrm{Sr} / \mathrm{CaO}$ ratio line of calcareous oozes (Karpoff, 1989).

to occur. It is thus likely that these rocks have been exposed on the seafloor, where they underwent a superficial evolution including faulting, disaggregation, slumping, etc. Mafic components may derive from nearby scarps that expose forearc crustal basement or may be from volcanics that were emplaced previously within the ultramafic rocks. Although metabasalt clasts are present in Subunit IIA, it appears that this interval suffered less intense reworking and mixing. We may interpret this unit as resulting from the rapid emplacement of a serpentine-rich debris flow in which some exotic clasts have been incorporated. A second major limit is represented by the interval from which a foraminifer-rich serpentine microbreccia (Sample 15) was recovered. Fossils present indicate that this rock was exposed on the flank of the seamount during the Pleistocene, $1.45 \mathrm{Ma}$. Occurrence of aragonite needles within this sample confirms that this
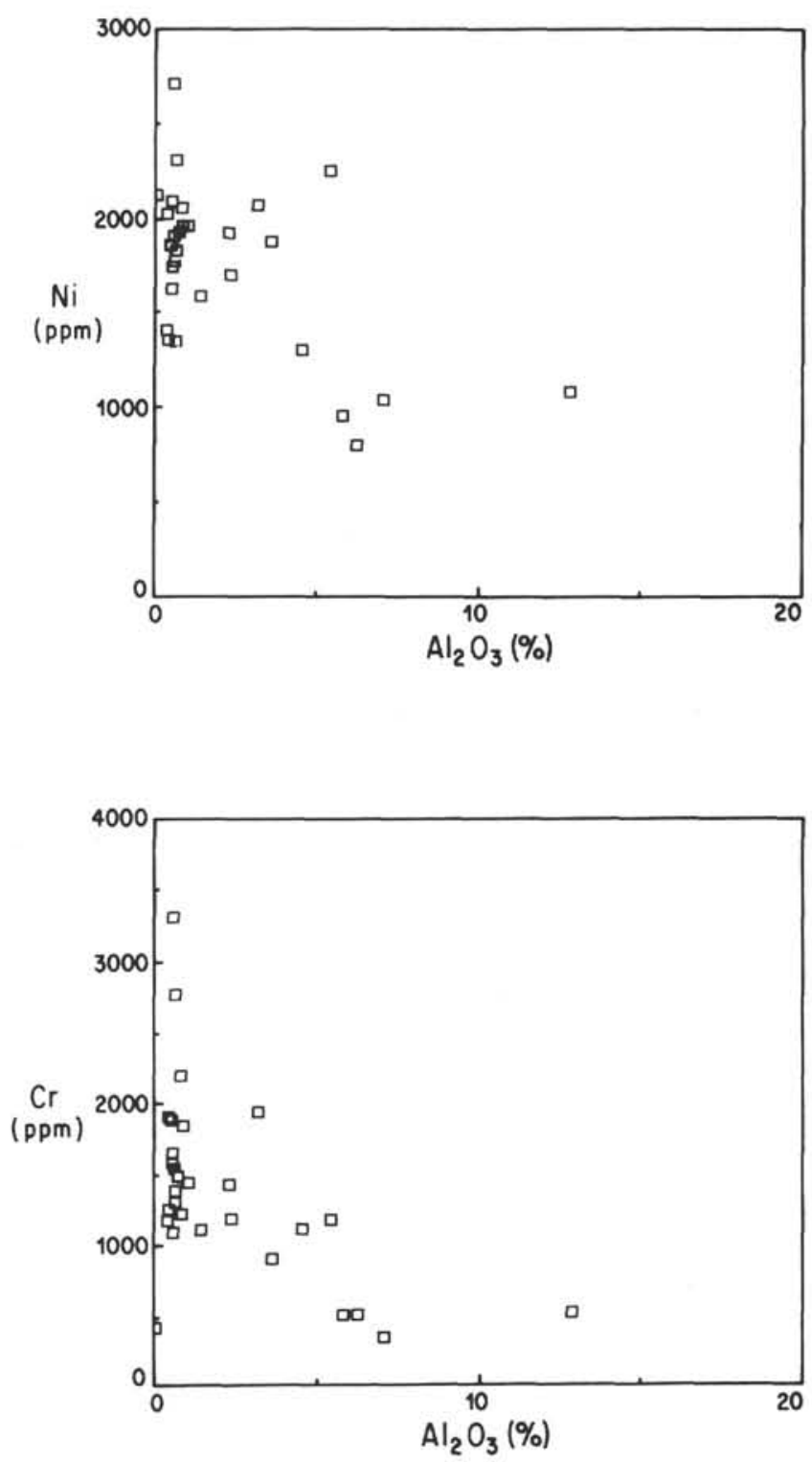

Figure $15 . \mathrm{Ni}$ and $\mathrm{Cr}$ vs. $\mathrm{Al}_{2} \mathrm{O}_{3}$ diagrams for the analyzed samples from Hole $778 \mathrm{~A}$. High $\mathrm{Al}_{2} \mathrm{O}_{3}$ percentages correlate with low nickel and chromium.

sediment underwent fluid interaction similar to that taking place at present on the flank of the seamount. This rather old superficial sediment is now found at about 22 mbsf within the serpentine section. This implies necessarily that it was subsequently covered by allochthonous serpentinitic material. This allochthonous material may very well be a new debris flow. In that simple case, at least three superposed serpentine flows were recovered in Site 778. In a more complex hypothesis, Sample 15 may have reached its present position because it was incorporated within a more important debris flow, which involved a significant pile of the seamount flank. Therefore, no definite constraints should exist on the detailed flow-stratigraphy of the hole.

\section{ACKNOWLEDGMENTS}

This work was supported by INSU-ODP France-Océanoscope grants. We recognize the efforts of Patty Fryer, Julian Pearce, and other shipboard scientists, marine technicians, and the crew of the JOIDES Resolution toward the success of drilling the serpentine 


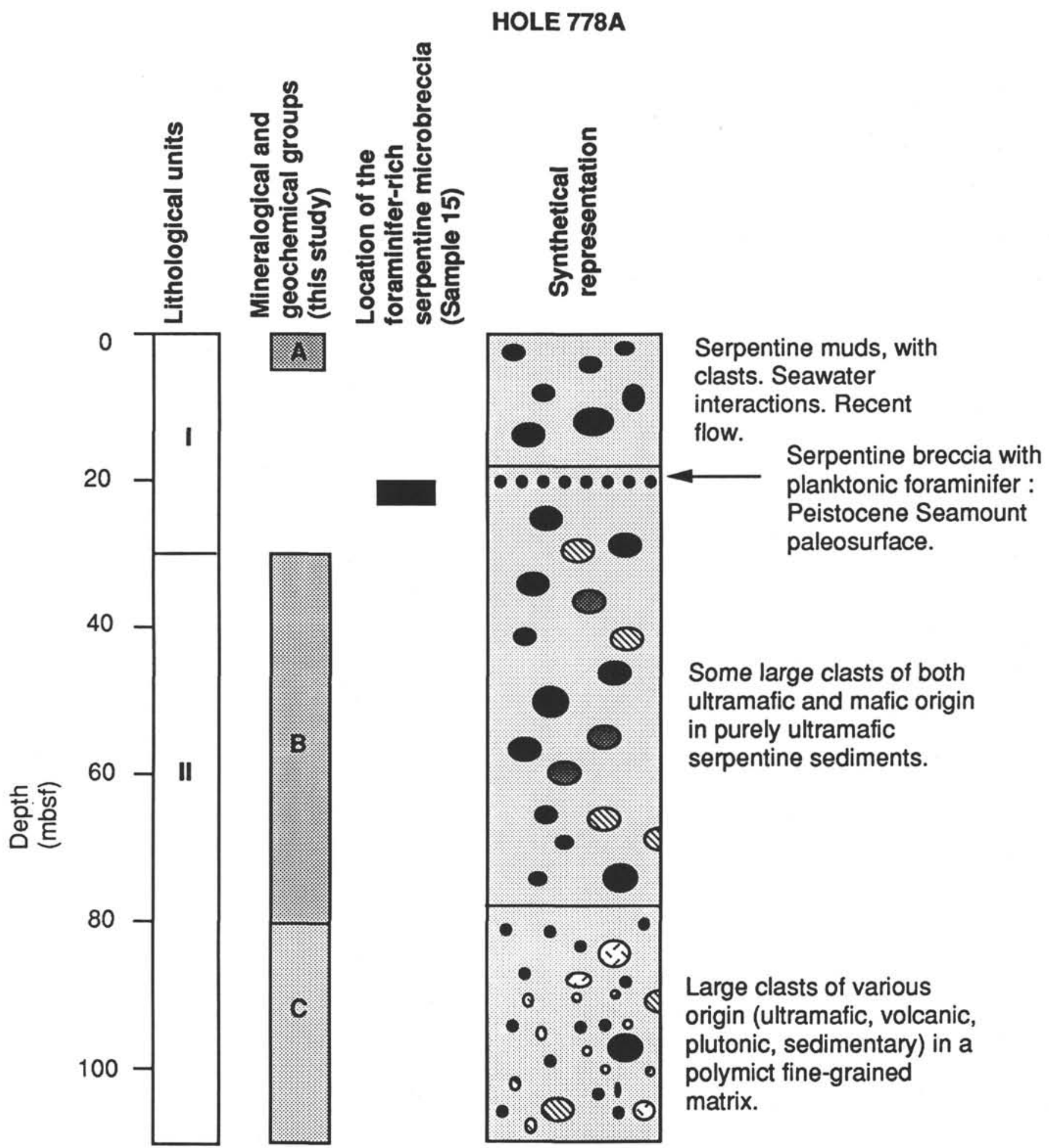

Figure 16. Summary lithologic column of Site 778 showing the main results and interpretations of this study. 
muds on the flanks of the Conical Seamount. We thank Patty Fryer, Lynn Johnson, and Jacques Girardeau for their help and comments during this work. John Sinton and an anonymous reviewer provided detailed and constructive reviews of the manuscript.

\section{REFERENCES}

Bonatti, E., Honnorez, J., and Gartner, S., 1973. Sedimentary serpentinites from the Mid-Atlantic ridge. J. Sediment. Petrol., 43:728-735.

Bonatti, E., and Joensuu, O., 1968. Palygorskite from Atlantic deep-sea sediments. Am. Mineral., 53: 975-983.

Bonatti, E., Lawrence, J. R., Hamlyn, P. R., and Breger, D., 1980. Aragonite from deep-sea ultramafic rocks. Geochim. Cosmochim. Acta, 44:1207-1214.

Bonatti, E., Simmons, E. C., Breger, D., Hamlyn, P. R., and Lawrence J., 1983. Ultramafic rock-seawater interaction in the oceanic crust: $\mathrm{Mg}$ silicate (sepiolite) deposit from the Indian Ocean floor. Earth Planet. Sci. Lett., 62:229-238.

Bowles, F. A., Angino, E. A., Hosterman, J. W., and Galle, O. K., 1971. Precipitation of deep-sea palygorskite and sepiolite. Earth Planet. Sci. Lett., 11:415-432.

Brindley, G. W., and Brown, G. (Eds.), 1980. Crystal Structures of Clay Minerals and Their X-ray Identification. Min. Soc. Monogr., 5.

Brindley, G. W., and Kikkawa, S., 1979. A crystal-chemical study of $\mathrm{Mg}, \mathrm{Al}$ and $\mathrm{Ni}, \mathrm{Al}$ hydroxy-perchlorates and hydroxy-carbonates. $\mathrm{Am}$. Mineral., 64:836-843.

Crovisier, J. L., 1989. Dissolution des verres basaltiques dans l'eau de mer et dans l'eau douce [Thèse Doc. Univ.]. U.L.P., Strasbourg, France.

Crovisier, J. L., Honnorez, J., and Eberhard, J. P., 1987. Dissolution of basaltic glass in seawater: mechanism and rate. Geochim. Cosmochim. Acta, 51:2977-2990.

Fryer, P., Ambos, E. L., and Hussong, D. M., 1985. Origin and emplacement of Mariana forearc seamounts. Geology, 13:774-777.

Fryer, P., and Fryer, G. J., 1987. Origins of non-volcanic seamounts in a forearc environment. In Keating, B. H., Fryer, P., Batiza, R., and Boehlert, G. W. (Eds.), Seamounts, Islands and Atolls. Am. Geophys. Union, Geophys. Monogr. Ser., 43:61-72.

Fryer, P., Haggerty, J., Tilbrook, B., Sedwick, P., Johnson, L. E., Saboda, K. L., Newsom, S. Y., Karig, D. E., Uyeda, S., and Ishii, T., 1987. Results of studies of Mariana forearcs serpentinite diapirism. Eos, 68:1534.

Fryer, P., Pearce, J. A., Stokking, L. B., et al., 1990. Proc. ODP, Init. Repts., 125: College Station, TX (Ocean Drilling Program).

Fryer, P., Saboda, K. L., Johnson, L. E., Mackay, M. E., Moore, G. F., and Dtoffers, P., 1990. Conical Seamount: SeaMARC II, Alvin submersible, and seismic-reflection studies. In Fryer, P., Pearce, J. A. Stokking, L. B., et al., 1990. Proc. ODP, Init. Repts., 125: College Station, TX (Ocean Drilling Program), 69-80.

Haggerty, J. H., 1987. Petrology and geochemistry of Neogene sedimentary rocks from Mariana forearc seamounts. In Keating, B. H., Fryer, P., Batiza, R., and Boehlert, G. W. (Eds.), Seamounts, Islands and Atolls. Am. Geophys. Union, Geophys. Monogr. Ser., 43:175-186.

Hathaway, J. C., and Sachs, P. L., 1965. Sepiolite and clinoptilolite from the Mid-Atlantic ridge. Am. Mineral., 50:1331-1347.

Honnorez, J., and Kirst, P., 1975. Petrology of rodingites from the Equatorial Mid-Atlantic fracture zones and their geotectonic significance. Contrib. Mineral. Petrol., 49:233-257.

Hussong, D. M., and Fryer, P., 1985. Forearc tectonics in the Northern Mariana arc. In Nasu, N. (Ed.), Formation of Active Ocean Margin: Tokyo (Terra Scientific), 273-290.

Johnson, L., and Fryer, P., 1990. The first evidence for MORB-like lavas from the outer Mariana forearc: geochemistry, petrography and tectonic implications. Earth Planet. Sci. Lett., 100:304-316.
Karpoff, A. M., 1989. Les faciès pélagiques condensés cénozoïques des océans Pacifique et Atlantique: témoins des grandes crises géodynamiques [Thèse Doc. Univ.]. U.L.P., Strasbourg, France.

Karpoff, A. M., Guennoc, P., and Jeudy de Grissac, C., 1988. Sédiments et dépôts métallifères des fosses de la région Nord de la Mer Rouge. Coll. Nat. sur l'Hydrothermalisme Océanique. PNEHO, Brest, France, 103-105.

Karpoff, A. M., Lagabrielle, Y., Boillot, G., and Girardeau, J., 1989. L'authigenèse océanique de palygorskite par halmyrolyse de péridotites serpentinisées (Marge de Galice): ses implications géodynamiques. C. R. Acad. Sci. Ser. 2, 308:1341-1348.

Kimball, K. L., Spear, F. S., and Dick, H.J.B., 1985. High temperature alteration of abyssal ultramafics from the Islas Orcadas Fracture zone, South Atlantic. Contrib. Mineral. Petrol., 91:307-320.

Lagabrielle, Y., and Polino, R., 1985. Origine volcano-détritique de certaines prasinites des schistes lustrés du Queyras (France): arguments texturaux et géochimiques. Bull. Soc. Geol. Fr., 4:461-471.

Lalou, C., Thompson, G., Arnold, M., Brichet, E., Druffel, E., and Rona, P. A., 1990. Geochronology of TAG and Snakepit hydrothermal fields, Mid-Atlantic Ridge: witness to a long and complex hydrothermal history. Earth Planet. Sci. Lett., 97:113-128.

Leg 125 Scientific Party, 1989. ODP Leg 125 drills forearc crust, mantle. Geotimes, 34:18-20.

Lockwood, J. P., 1971a. Detrital serpentinite from the Guajira Peninsula, Colombia. Mem.-Geol. Soc. Am., 130:55-75.

, 1971b. Sedimentary and gravity slide emplacement of serpentinite. Mem.-Geol.Soc. Am., 82:919-936.

McKenzie, J. A., Isern, A., Karpoff A. M., and Swart, P. K., 1989. Basal dolomitic sediments, Tyrrhenian Sea, ODP Leg 107. In Kastens, K. A., Mascle, J., Auroux, C., et al., Proc. ODP, Init. Repts., 107: College Station, TX (Ocean Drilling Program), 141-152.

Miyata, S., 1975. The synthesis of hydrotalcite-like compounds and their structures and physico-chemical properties. I: the systems $\mathrm{Mg}^{2+}$. $\mathrm{Al}^{3+}-\mathrm{NO}_{3}^{-}, \mathrm{Mg}^{2+}-\mathrm{Al}^{3+}-\mathrm{Cl}^{-}, \mathrm{Mg}^{2+}-\mathrm{Al}^{3+}-\mathrm{ClO}_{4}, \mathrm{Ni}^{2+}-\mathrm{Al}^{3+}-\mathrm{Cl}^{-}$and $\mathrm{Zn}^{2+}-\mathrm{Al}^{3+}-\mathrm{Cl}^{-}$. Clays Clay Miner. 23:69-375.

Mumpton, F. A., and Thompson, C. S., 1975. Mineralogy and origin of the Coalinga asbestos deposit. Clays Clay Miner., 23:131-143.

Page, N. J., 1968. Chemical differences among the serpentine "polymorphs." Am. Mineral., 53:201-215.

Schmitz, W., Singer, A., Bäcker, H., and Stoffers, P., 1982. Hydrothermal serpentine in a Hess Deep sediment core. Mar. Geol., 46:M17-M26.

Shipboard Scientific Party, 1990a. Site 778. In Fryer, P., Pearce, J. A., Stokking, L. B., et al., 1990. Proc. ODP, Init. Repts., 125: College Station, TX (Ocean Drilling Program), 97-114.

- 1990b. Site 779. In Fryer, P., Pearce, J. A., Stokking, L. B., et al., 1990. Proc. ODP, Init. Repts., 125: College Station, TX (Ocean Drilling Program), 115-145.

Taylor, R. M., and McKenzie, R. M., 1980. The influence of aluminium on iron oxides. VI. The formation of $\mathrm{Fe}$ (II)-Al(III) hydroxy-chlorides, -sulfates, and -carbonates as new members of the pyroaurite group and their significance in soils. Clays Clay Miner., 28:179-187.

Taylor, R. M., 1984. The rapid formation of crystalline double hydroxy salts and other compounds by controlled hydrolysis. Clay Miner., 19:591-603.

Whittaker, E.J.W., and Zussman, J., 1956. The characterization of serpentine minerals by X-ray diffraction. Mineral. Mag., 31:107-125.

Wicks, F. J., and O'Hanley, D. S., 1988. Serpentine minerals: structure and petrology. In Bailey, S. W. (Ed.), Hydrous Phyllosilicates. Rev. Mineral., Min. Soc. Am., 19:91-101.

Date of initial receipt: 3 October 1990

Date of acceptance: 11 September 1991

Ms 125B-175 